\author{
Cadernos de \\ ESTUDOS LINGüĺSTIICOS - (56.1), Campinas, Jan./Jun. 2014
}

\title{
A TEORIA DO METRO DE FABB \& HALLE E O DECASSÍLABO PORTUGUÊS ${ }^{1}$
}

\author{
BEETHOVEN BARRETO ALVAREZ \\ UFF/UNICAMP
}

\author{
Numeros memini, si verba tenerem \\ Lembrarei os ritmos, se recordar as palavras \\ (Verg. Ecl. 9, 45)
}

\begin{abstract}
RESUMO: Neste artigo, pretendo primeiramente expor a teoria sobre o metro proposta por Nigel Fabb \& Morris Halle, em Meter in Poetry: A new theory (CUP, 2008), para, em seguida, aplicar seu aparato conceitual a versos decassílabos da tradição poética portuguesa e brasileira, tendo como base versos desde Sá de Miranda até Januário da Cunha Barbosa, indo do século XVI ao XIX, com objetivo de ampliar as análises de Fabb \& Halle, que consideraram apenas muito brevemente versos em português em seu estudo, e propor uma explicação para a diversidade acentual do decassílabo, demonstrando como o metro decassílabo, de natureza iâmbica, ou seja, com acentuação em sílabas pares, comporta acentos em sílabas ímpares. Após a aplicação da teoria de Fabb \& Halle ao metro português, pretendo ainda discutir as falhas e lacunas apontadas pelas diversas revisões que recebeu o trabalho desses linguistas, em especial, confrontando os resultados da aplicação da teoria com as propostas de solução da métrica tradicional, para, ao final, destacar as possibilidades de trabalho com a nova teoria e entrever seus limites, sempre com ênfase no metro decassílabo português.
\end{abstract}

Palavras-chave: Fonologia Gerativa, teoria do metro poético, decassílabo

ABSTRACT: In this paper, firstly I aim to expose the theory on meter proposed by Nigel Fabb and Morris Halle, in the book "Meter in Poetry: A new theory" (CUP, 2008), and then apply their conceptual apparatus to decassílabos of the Portuguese and Brazilian poetic tradition, from Sá de Miranda to Januário da Cunha Barbosa, ranging from the sixteenth to the nineteenth century, in order to extend the analysis of Fabb \& Halle, who very briefly considered verses in Portuguese in their study, and in order to propose an explanation for the accentual diversity of the decassílabos, demonstrating how this meter of iambic nature, ie, with accentuation on pairs syllables, behaves accepts on odd syllables. After application of Fabb \& Halle's theory to the Portuguese meter, I still intend to discuss the flaws and shortcomings pointed out by several reviews that the work of these linguists received and compare the results of this application with other solutions from traditional metrics, for lastly point out possibilities of work with this new theory and show its limits, always with emphasis on the Portuguese decassílabo meter.

Key-words: Generative Phonology, theory of poetic meter, Portuguese decassílabo

${ }^{1}$ Agradeço o apoio da professora Bernadete Abaurre para a realização deste trabalho e também as atentas leituras dos professores Plínio Barbosa e Filomena Sandalo. 


\section{INTRODUÇÃO}

Para os estudos das relações entre Métrica e Fonologia, ${ }^{2}$ na Linguística Gerativa, costuma-se considerar o final da década de 1960 como um momento inaugural. Bruce Hayes $^{3}$, por exemplo, e diversos outros linguistas ${ }^{4}$ situam aí o surgimento mais ou menos formal da "Métrica Gerativa" (Generative Metrics), ${ }^{5}$ referindo-se aos trabalhos de Morris Halle e Samuel Jay Keyser aplicados ao verso da língua inglesa, em especial ao seminal "Chaucer and the study of prosody" (1966) e também a Keyser (1969) e Halle \& Keyser (1971 e 1972). Esses trabalhos, de alguma forma, seguiam o caminho aberto por Noam Chomsky, depois de Syntactic Structures (1957) e seus desdobramentos, aplicando ao estudo da métrica o aparato conceitual da Gramática Transformacional, e por Chomsky \& Morris Halle, Sound Pattern of English, SPE (1968), a partir das discussões sobre o padrão acentual do inglês. ${ }^{6}$

Halle \& Keyser (daqui para frente $H \& K$ ) propunham que o metro poético deveria ser explicado como uma abstração com a qual haveria uma correspondência dos elementos fonológicos identificáveis na "superfície" do verso. A correta correspondência entre esses elementos, então, seria definida por uma espécie de "gramática métrica" que consistiria de um conjunto de restrições. As restrições especificariam, na verdade, as condições dentro das quais uma determinada representação fonológica formaria um composto métrico correto, ou seja, um verso métrico. ${ }^{7}$ Essa série de restrições e condições que demonstram a abstração do metro foram expostas na forma de um modelo do pentâmetro iâmbico inglês como uma série de dez posições/sílabas "fracas", W (weak), e "fortes", S (strong), WS WS WS WS WS: ${ }^{8}$

(1) Shall I compare thee to a summer's day?

(Shakespeare,Sonetos, 18.1)

W S W S W SW S W S

"Hei de comparar-te com um dia de verão?"

${ }^{2}$ Para uma revisão mais aprofundada sobre os primeiros desenvolvimentos da métrica gerativa, ver Holder (1995, p. 65-84). Já para um panorama sintético de todo o percurso da métrica gerativa, ver Brogan \& Blumenfeld (2012, p. 547-8). Hanson (2011) apresenta o estado da arte da questão modernamente de forma muito esclarecedora.

${ }^{3}$ Cf. Hayes (1988, p. 220; 2008, p. 2015).

${ }^{4}$ Ver a bibliografia comentada em Brogan (1999 [1981]). Entre colchetes indicarei a data da $1^{\mathrm{a}}$ edição, quando for importante historicamente.

${ }^{5} \mathrm{O}$ termo foi originalmente cunhado por J. C. Beaver, em Beaver (1971, p. 177).

${ }^{6}$ Cf. Halle \& Keyser (1971, p. xiii).

${ }^{7}$ Não vou me referir neste trabalho em nenhum momento aos chamados versos livres. Contudo, para uma boa consideração sobre o tema, ver Steele (1990).

${ }^{8} \mathrm{O}$ que pode parecer apenas uma representação alternativa para as tradicionais sílabas breves ( $)$ ) e longas (-), ou leves (light) e pesadas (heavy), não é só isso. Na verdade, o modelo halle-keyseriano destaca um template do metro como uma abstração, ou seja, como um elemento suprassegmental à sucessão de itens fonológicos superficiais: fonemas e sílabas. Assim, o metro não "estaria dentro" do verso, mas antes o verso respeitaria condições impostas pelo próprio metro (como ente abstrato). Em H\&K (1971, p. 165), o exemplo original era: The cúrfew tólls the knéll of párting dáy [O toque de recolher bate o sino do dia que está acabando]. E o padrão que prevê todas as possibilidades do pentâmetro era: (W)SWSWSWSWS(W)(W). 
O modelo de H\&K, que inaugura, de certa maneira, a "Métrica Gerativa" (MG), passa a se preocupar com questões relativas à "boa formação" (wellformedness) do verso na poesia. Assumindo que "um metro é uma forma rítmica abstrata, internalizada por aqueles que detêm autoridade na tradição métrica autorizada", como vai definir mais tarde Hayes (1988, p. 220), caberia ao linguista investigar quais regras explicariam a boa formação de um verso. Assim como um conjunto de regras sintáticas produz uma grande variedade de padrões sintáticos, como explica a gramática transformacional, H\&K propunham que um conjunto de princípios ou regras, por sua natureza, produziria uma grande variedade de padrões métricos (1966, p. 191). ${ }^{9}$

$\mathrm{Na}$ esteira do desenvolvimento dessas ideias, Magnuson \& Ryder (1970 e 1971) propuserem uma segunda teoria, num artigo que primeiramente se ocupa em criticar H\&K por inadequações e imprecisões (cf. Magnuson \& Ryder, 1970, p. 792 et seq.). A teoria de Magnuson \& Ryder considera, então, que "metros poéticos são padrões abstratos que não possuem nenhuma relação efetiva com os padrões naturais da linguagem" (p. 801) e propõe uma grade métrica de dez posições, cinco pares (E, “even") e cinco ímpares (O, “odd”), em que cada sílaba deve ser considerada como um conjunto de quatro características distintivas: $[ \pm$ Strong, ST, forte], [ \pm Weak, WK, fraca], [ \pm Word Onset, WO, início de palavra] e [ \pm Pre-Strong, PS, pré-forte], o que representaria, a partir de regras-base, a organização prosódica do metro. No centro da teoria, estava a concepção de que existiria uma "Matriz Expectativa" (Expectation Matrix), uma combinação ideal de características para uma posição métrica par (Strong) e uma combinação ideal, ou um tipo de sílaba ideal para uma ímpar (Weak), combinação essa que seria expressa da seguinte forma:

$\begin{array}{lll} & \text { E } & \text { O } \\ \text { WO } & + & - \\ \text { WK } & - & + \\ \text { ST } & + & - \\ \text { PS } & - & +\end{array}$

De acordo com Magnuson \& Ryder (1971, p. 800), satisfazer completamente essa matriz ideal seria impossível, assim, os autores atacam qualquer objetivo de classificação de versos como "métricos" e "não métricos", alegando que nenhum verso satisfaria completamente um padrão métrico abstrato. ${ }^{10}$

${ }^{9}$ Embora amplamente aceitas as ideias de H\&K, obviamente também foram alvo de críticas. Cf. Bowley (1974, pp. 5-19) e Sledd (1969, p. 71-4). Bowley, por exemplo, seguindo modelos tradicionais, entendia que "variação métrica (...) se explica por diferenças nos padrões métricos subjacentes, não por diferenças na forma como se aplicam as regras de correspondência" [metrical variation is (...) accounted for by differences in the underlying metrical patterns, not by differences in the way the correspondence rules apply].

${ }^{10}$ Sobre críticas ao modelo de Magnuson \& Ryder, ver Beaver (1971). Ainda Brogan (1999), que diz o seguinte sobre a teoria de M\&R: "É seguro dizer que até hoje a abordagem deles tem sido considerada infrutífera pela maioria dos metricistas" [It is fair to say that so far their approach has been considered unfruitful by most metrists]. 
Tanto a ideia da "Matriz Expectativa" quanto a ideia da dissociação entre parâmetros de constituição métricos e padrões naturais da linguagem comum parecem não ter ganhado muito eco nas futuras pesquisas, ${ }^{11}$ contudo, mesmo essa ideia de quase completa "não-metricalidade" dos versos partia do princípio de uma "prosódia" regulada e geradora., já que seria função do prosodista, na concepção de Magnuson \& Ryder, formular "regras-base" de formação do metro, a partir das quais e, principalmente, das restrições impostas por essas regras, o poeta faria suas escolhas (1971, p. 801-2).

Depois, uma terceira visão se apresenta: Kiparsky (1977), ${ }^{12}$ partindo do metro inglês, sugere então que o metro não seja apenas uma sucessão de posições/sílabas fracas e fortes, mas sim que seja organizado de uma forma hierárquica entre seus constituintes, no que se diferencia de $H \& K$, mas assume que o metro seja um padrão abstrato, mais ou menos como H\&K.

A grande mudança paradigmática do trabalho de Kiparsky são as observações de Liberman (1975), em The intonational system of English (sua tese de doutorado), que propôs adotar uma divisão do verso em que a notação não se baseasse em uma contagem/numeração das sílabas/posições, mas sim em padrões acentuais representados como "árvores" (trees).

Essa "hierarquização em árvore" das sílabas de um verso pode ser demonstrado da seguinte forma, a partir da escansão do mesmo verso anterior, utilizando o esquema proposto em $\operatorname{Kiparsky~(1977,~p.~230):~}{ }^{13}$

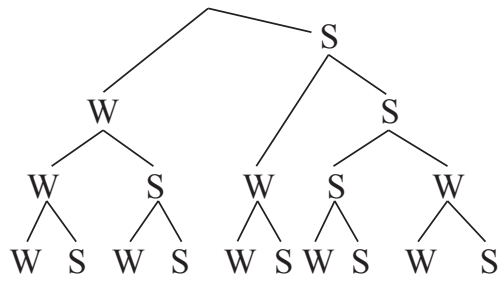

Shall I compare thee to a summer's day?

Assim, já por volta de 1977, o termo "métrica gerativa” já abrangia essas três diferentes teorias, com praticamente as mesmas bases da gramática transformacional e da fonologia gerativa. Em comum, essas teorias reconheciam o metro como um padrão abstrato mais ou menos análogo à estrutura da própria linguagem, sendo cada verso poético um constituinte da realização desse metro.

A partir da década de 1980, com o desenvolvimento da Fonologia Métrica, diversos trabalhos com abordagens teóricas próximas ampliaram as discussões da MG, como Hayes (1983, 1988, 1989), Prince (1989), Hammond (2001), Hanson \& Kiparsky (1996), Golston (1998), Golston \& Riad (2000) e Hanson (2009a e 2009 b), só para citar alguns. ${ }^{14}$

\footnotetext{
${ }^{11}$ A favor de Magnuson \& Ryder, ver Attridge (1982).

${ }^{12}$ Também Piera (1980), aplicando a teoria de Kiparsky ao metro espanhol.

${ }^{13}$ Kiparsky também adota a tradicional classificação em pés (iâmbicos, trocaicos, etc.) da Métrica Clássica utilizada pela Fonologia Métrica.

${ }^{14}$ Ver Brogan (1999) para um panorama mais completo sobre a produção na área.
} 
Contudo, embora haja teorias diferentes, segundo Hanson (2011, p. 47), ${ }^{15}$ haveria três premissas comuns a todos os estudos da MG nesses mais de 50 anos, que, especialmente, os categorizam como tal: (1) primeiro, em todas as teorias métricas gerativas, o metro é um conhecimento que o poeta ou o público possui acerca de um determinado padrão. Esse conhecimento incluiria intuições sobre metricalidade, bem como intuições sobre complexidade; essa perspectiva seria gerativa no sentido de que esse conhecimento "sabe" caracterizar não apenas os exemplos existentes do metro, mas também aqueles potenciais. (2) A segunda premissa, comum a todos os trabalhos em métrica gerativa, é que tal conhecimento métrico é um conhecimento linguístico. Assume-se que o metro em qualquer língua faz uso das mesmas entidades e princípios para se combinar que estão envolvidos na gramática. ${ }^{16}$ (3) A terceira premissa distinta da métrica gerativa é que essas entidades (os metros) e os princípios (que regem o conhecimento métrico) são dados por uma faculdade humana inata e especificamente linguística, chamada gramática universal. ${ }^{17}$ Descobrir no que tal gramática universal consiste é o projeto central de investigação da gramática gerativa, e, segundo Hanson (2011), é o "real entrelaçamento dos estudos métricos com esse projeto, na prática, o que mais distingue a métrica generativa".

Buscando investigar exatamente esses mecanismos geradores do metro, recentemente, em 2008, Nigel Fabb, professor de Linguística Literária na Universidade de Strathclyde, e Morris Halle, cofundador da fonologia gerativa ao lado de Chomsky e Professor Emérito do MIT, juntaram-se para propor uma nova teoria do metro poético.

Meu trabalho parte daí então: pretendo (1) expor a teoria proposta por Nigel Fabb \& Morris Halle, em Meter in Poetry: A new theory (CUP, 2008), para, em seguida, (2) aplicar seu aparato conceitual a versos decassílabos da tradição poética portuguesa e brasileira, ${ }^{18}$ com objetivo de: (a) ampliar as análises de Fabb \& Halle, já que em seu livro, apenas pouquíssimos versos em português foram objeto de estudo, e (b) tentar propor uma explicação para a diversidade acentual do decassílabo.

Alguns metricistas do verso português há muito apontam para um certo ritmo iâmbico no decassílabo da poesia portuguesa, como Castilho (1851), Azevedo Filho (1962, 1971) e Chociay (1974). Também estudiosos da Fonologia já fizeram associação do decassílabo português ao pentâmetro iâmbico (iambic pentameter) inglês, como Bello (1955), Piera (1980), Nespor \& Vogel (1986), Hanson (1996), entre outros. Contudo, não pude identificar nenhum trabalho específico no sentido de demonstrar como essa relação se mostra no metro em língua portuguesa. Assim, neste trabalho, pretendo verificar essa hipótese com a teoria de Fabb \& Halle e ainda demonstrar como o metro (iâmbico) decassílabo, mesmo com acentuação em sílabas pares, comporta acentos em sílabas ímpares - o que se demonstrará aceitável de acordo com a teoria e o que, a meu ver, carecia de uma nova abordagem.

\footnotetext{
${ }^{15}$ Aqui cabe um agradecimento à professora Kristin Hanson, que gentilmente me cedeu uma cópia do seu trabalho de difícil acesso no Brasil.

${ }^{16}$ Cf. Jakobson (1960), Kiparsky (1987) e Hayes (1988), por exemplo.

${ }^{17}$ Cf. Chomsky (1972).

${ }^{18}$ Usarei exemplos de Sá de Miranda e Camões a Januário da Cunha Barbosa, ou seja, de mais ou menos 1530 a 1830 . Na seção 3, serão melhor explicados os motivos.
} 
Outros linguistas, como Kiparsky (2009), Dell (2009), Hammond (2010), Hayes (2010) e Riad (2010), em revisões do trabalho de Fabb \& Halle, indicaram algumas falhas e lacunas, como o retorno a uma teoria baseada em regras e a falta de diálogo aberto com teorias anteriores. Essas considerações serão úteis para criticar algumas ideias de Fabb \& Halle. ${ }^{19}$ Assim, após a aplicação da teoria no metro português, pretendo discutir as falhas e lacunas apontadas por essas diversas revisões, em especial, confrontando os resultados da aplicação da teoria com as propostas de solução da métrica tradicional, para, ao final, apontar possibilidades de trabalho com a nova teoria e entrever seus limites, sempre com ênfase no metro decassílabo português.

\section{A TEORIA DO METRO POÉTICO DE FABB \& HALLE}

Metro em Poesia: Uma nova teoria, numa tradução livre, é o título do livro de Nigel Fabb em parceria com Morris Halle, cujo objetivo é apresentar uma nova teoria do metro poético para explicar os metros de qualquer tipo conhecido de verso métrico. ${ }^{20}$ Isso Fabb \& Halle (daqui para frente F\&H) fazem de forma muito técnica, porém simples, em uma abordagem unificada e ilustrada com análises detalhadas de poemas em várias línguas.

Depois de detalhar o funcionamento da teoria no capítulo 1, " $A$ theory of poetic meter" ("Uma teoria do metro poético, pp. 1-43), F\&H demonstram sua aplicação nos metros da tradição poética inglesa, valendo-se de seus vários gêneros, nos capítulos 2 e 3, "English strict meters" ("Metros estritos ingleses", pp. 44-66) e "English loose meters" ("Metros soltos ingleses", pp. 67-93). ${ }^{21}$ Ainda lidam com os metros do francês (pp. 133-152), do grego antigo (pp. 153-185), do árabe clássico (pp. 186-213), do sânscrito (pp. 214-237), do letão (pp. 238-250), de outras tradições métricas, como o chinês e o vietnamita, o árabe vernacular e o inglês antigo, em "Meters of the world" ("Metros do mundo", pp. 251-267)

${ }^{19}$ Apenas pelo número de revisões, embora muito críticas, que recebeu o trabalho de Fabb \& Halle, já se percebe a importância da obra.

${ }^{20}$ Uma vez que a teoria se atém fundamentalmente ao verso metrificado, tanto no livro de $\mathrm{F} \& \mathrm{H}$ quanto neste trabalho, o verso livre não será objeto de estudo. Como a teoria se baseará na repetição de padrões rítmicos, a justificativa para a não inclusão desse tipo de verso é que o verso livre "não se baseia em um consensual conjunto de princípios e unidades, mas sim cada poema - e muitas vezes também cada verso do poema - é baseado em princípios e unidades próprios, e o poema atinge o seu impacto estético, pedindo ao leitor ou ouvinte para descobrir as unidades e os princípios que dão forma ao verso. O único aspecto que compartilha o verso livre com outros tipos de poesia é a divisão em versos (lineation): até mesmo o tipo mais experimental de verso livre é composto em versos" [does not rest on a generally agreed upon set of principles and units; rather each poem - and often also each line in the poem - is based on principles and units of its own, and the poem achieves its esthetic impact by asking the reader or listener to discover the units and principles that give shape to the line. The one aspect that Free Verse shares with other kinds of poetry is lineation: even the most experimental kind of Free Verse is composed of lines]. F\&H (2008, p. 3).

${ }^{21}$ Os metros soltos (loose meters) são metros, segundo as regras da nova teoria de F\&H, aos quais outras regras que não as iterativas são empregadas para explicar seu funcionamento. Não discutiremos essa parte da teoria neste trabalho. 
e ainda do hebraico bíblico, no último capítulo, "The metrical poetry of the Old Testament" ("A poesia métrica do Antigo Testamento", pp. 268-284). Ainda há um capítulo, "Southern Romance" ("Línguas neolatinas do sul", pp. 94-132), escrito em colaboração por Carlos Piera, que dá conta de tratar da métrica do espanhol renascentista (e, por associação, um pouco do português dessa época), do italiano de Petrarca, do galego-português dos Cancioneiros e ainda do verso satúrnio do latim arcaico e da poesia hispano-judaica da Idade Média.

O objetivo geral da teoria e, portanto, do livro como um todo é fornecer um quadro de regras e condições para caracterização dos vários metros dentro das várias tradições poéticas. Partindo de uma perspectiva da "métrica gerativa", essa nova teoria do metro também se pretende uma teoria da "boa formação" do metro. Assim, em última análise, a teoria trata das regras e condições para a boa formação do metro.

O ponto de partida de todo o arcabouço teórico de F\&H é o verso, ou melhor, aquilo que configura um verso. Em sua teoria, a distinção básica entre prosa e poesia reside num "quê" que distingue um verso de uma sequência de texto em prosa simplesmente dividida em linhas. Seria esse conceito, ou antes, essa configuração do verso que, em qualquer tradição literária, definiria o que é poesia. ${ }^{22}$

Para que um verso seja reconhecido como um verso dentro de uma tradição poética, ele precisa satisfazer um conjunto de condições que o fazem ser reconhecido como um verso. ${ }^{23}$ No caso da poesia métrica, objeto de estudo da teoria, os versos precisam satisfazer condições de tamanho e posicionamento de certas sílabas marcadas, ou seja, que se distinguem de outras, em especial, por sua proeminência acentual. ${ }^{24}$

O resultado desse conjunto (set) de condições seria um verso (line) de determinado tamanho, que, em conjunto com essa marcação das sílabas, criaria um ritmo definido. Este é um ponto fundamental da teoria de F\&H: o ritmo surge como produto final das restrições de tamanho do verso e do posicionamento (sucessão e repetição) de sílabas marcadas. Ou seja, a teoria não tem como foco o estudo do ritmo, antes seu objeto é o próprio verso e o que restringe seu tamanho. Essa premissa se opõe fundamentalmente à concepção do metro da métrica tradicional.

Para F\&H, o tamanho do verso não é medido pela contagem direta das sílabas, mesmo que as sílabas na teoria se mantenham como unidade importante. Assim, o tamanho do verso é calculado pelo agrupamento de determinadas sílabas do verso, agrupamento este imposto pela "projeção" ou "proeminência" de certas sílabas. E aqui se baseia um ponto fundamental da teoria: a projeção de linhas de grade que explicitem os mecanismos de agrupamento de sílabas e regulação do tamanho do verso formando um "grade métrica".

\footnotetext{
${ }^{22}$ Para uma ideia contrária, ver Jakobson (2011, p. 131).

${ }^{23}$ Interessante notar que a exposição da teoria e sua aplicação, no trabalho de F\&H, faz questão de desconsiderar a nomenclatura mais ou menos tradicional que registra a produção da área, na tentativa de evitar confusões terminológicas. Cf. F\&H (2008, p. 23-5). Assim também pautei a apresentação dos conceitos nesta seção.

${ }^{24}$ Sobre tradições poéticas não-métricas, como a tradição bíblica hebraica, F\&H apresentam um exemplo do conjunto de condições para a configuração do metro, cf. F\&H (2008, p. 1-3).
} 
O mecanismo de projeção e agrupamento de sílabas na composição de uma "grade métrica" que explicita padrões acentuais é uma derivação, como os próprios autores indicam (F\&H, 2008, p. 39; 2010, p. 6), dos estudos de Liberman (1975) e, principalmente, Idsardi (1992). Liberman (1975), ao propor uma teoria para explicar o acento, a entonação e o fraseamento e suas interações em nível prosódico e gramatical, sugeriu que as diferenças de proeminências de sílabas são resultado do agrupamento dessas sílabas, o que poderia ser demonstrado numa "grade métrica". ${ }^{25}$ Idsardi (1992) propôs uma organização dos agrupamentos que explicitam uma grade de proeminências (acentuais) por meio da projeção de asteriscos representativos de cada sílaba numa linha de grade, agrupados por parênteses, segundo regras iterativas de sequenciamento prosódico. Esse será o modelo base da teoria de F\&H: a criação de grades métricas projetadas por asteriscos e a inserção de parênteses que representam a organização das sílabas, por sua vez, agrupadas por regras iterativas.

Contudo, embora utilizem como modelos originários os trabalhos de Liberman e Idsardi, podemos verificar uma mudança de perspectiva teórica fundamental: para F\&H o metro não é simplesmente o resultado da análise de um verso, mas sim é uma constituição a parte. Não há um template a priori do metro que se aplica ao verso; antes, cada verso gera uma "grade métrica" que, caso se ajuste às condições e regras de formação das grades, se configura com uma grade bem formada, ou seja, um metro bem formado.

Vejamos a explicitação da teoria em termos práticos, com alguns exemplos. Na composição das grades métricas, as sílabas do verso devem ser projetadas e a projeção de cada sílaba deve ser representada por um asterisco numa linha abaixo do verso. A sucessão dos asteriscos que marcam as "projeções" será chamada de "linha de grade" (gridline): ${ }^{26}$

(4) Talhar no mármore divino

$* \quad * \quad * \quad * \quad * * * * \Delta \leftarrow$ Linha de grade (Gridline)

(5) Minha terra tem palmeiras

(Canção do Exílio, Gonçalves Dias) $* * * * * * \Delta \leftarrow$ Linha de grade (Gridline)

O símbolo $\Delta$ (delta) indica uma não-projeção de sílaba. Como utilizamos exemplos em português, precisamos lembrar que as eventuais sílabas pós-tônicas da última palavra de um verso (no caso de palavras paroxítonas e proparoxítonas) não contam para efeitos métricos, assim, na teoria são compreendidas como sílabas não-projetadas. Na seção seguinte, explicaremos melhor as regras de não-projeção.

${ }^{25}$ Depois, Liberman \& Prince (1977), Hayes (1981), Prince (1983), Halle \& Vergnaud (1987), Hayes (1995) publicaram estudos também baseados em agrupamento de sílabas e formação de grade métricas.

${ }^{26}$ Originalmente, F\&H utilizam exemplos em inglês para explicitar os conceitos básicos da teoria. Optei por já expor os fundamentos da teoria com exemplos em português, mas algumas características próprias do metro português, explicadas por regras opcionais da teoria, só serão melhor explicadas na seção seguinte. 
Nessa linha de grade projetada, é importante agrupar as projeções de sílabas. A base da teoria é esse agrupamento, porque a partir dele será projetada uma nova linha. Inserimos parênteses para criar os grupos (binários ou ternários) na linha de grade já projetada: inserem-se parênteses direitos, ), para agrupar sílabas à esquerda, como em (6) e parênteses esquerdos, (, para agrupar sílabas à direita, como em (7), até não haver mais como realizar agrupamentos:

(6) Talhar no mármore divino

)* $* * \quad *) * * * * \Delta$

(7) Minha terra tem palmeiras

$(* * * *(*) *(* *)$

(Canção do Exílio, Gonçalves Dias)

O que define o modo de inserção de parênteses é uma "regra de iteratividade" (iterative rule), ou seja, uma regra de repetições de padrões. Começando-se ou da direita para esquerda, como em (6), ou da esquerda para direita, como em (7), os parênteses denotam os padrões de repetição (que poderão ser binários ou ternários) de determinadas sílabas proeminentes na grade, chamadas de "cabeça" (head) do grupo e que serão projetadas na linha seguinte. Caso não seja possível mais repetir um padrão de repetição, não se inserem mais parênteses.

As regras de iteratividade que regem a montagem das linhas de grade são simples e comuns a todo e qualquer metro e são baseadas nestes cinco parâmetros:

(8) i. Inserção de parênteses que, ou começa justamente na margem da linha de grade, ou em um asterisco, ou dois asteriscos para dentro.

ii. Margem da sequência, esquerda (E) ou direita (D), onde a inserção começa.

iii. Natureza dos parênteses inseridos (E/D).

iv. Intervalo entre as inserções ( 2 ou 3 asteriscos).

v. Posição da cabeça de cada grupo (E/D).

Assim, podemos criar a linha de grade do verso seguinte, (9), em que os agrupamentos são de três sílabas agora -em (6) e (7) observamos grupos de duas sílabas. Para a teoria o que terá maior importância será a quantidade dos agrupamentos e não de sílabas:

(9) Pois choraste, meu filho não és!

(I-Juca-Pirama, Gonçalves Dias)

Nesta altura, podemos elencar duas regras básicas que deverão nortear a criação das grades: 
(10) Projete cada sílaba como um asterisco para formar a linha de grade 0. Algumas sílabas podem desrespeitar esta regra e não serão projetadas. Indique com o símbolo $\Delta$ (delta).

(11) Projete a cabeça de um grupo para formar a próxima linha de grade.

Ao se projetar a "cabeça" do grupo numa nova linha de grade 1 projetada a partir da grade 0, que é agrupada, por sua vez, também por uma regra de iteratividade, destaca-se a importância e função dos grupos de sílabas:

(12) Minha terra tem palmeiras

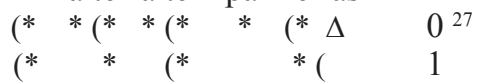

Podemos notar que nos exemplos do português as sílabas projetadas para a linha 1, ou seja, as cabeças dos grupos, são normalmente sílabas acentuadas. No caso do português, a acentuação silábica está intimamente ligada à marcação das sílabas ${ }^{28}$ e, de certa forma, determina sua projeção, mas nem todas as sílabas acentuadas lexicalmente serão projetadas. Segundo os conceitos da teoria de F\&H é preciso fazer uma distinção entre sílabas acentuadas e sílabas marcadas (ou proeminentes) que desempenham um determinante papel na construção das grades (e dos metros), que serão então chamadas de maxima (sg. maximum), em português, "máximas". As "máximas" são sílabas que obrigatoriamente devem ser projetadas. De acordo com a tradição poética de cada língua, as regras que definem e restringem a projeção das máximas poderão variar, mas sempre possibilitarão a construção de grades que explicitarão a boa formação do metro. No português, então, a regra que explica a projeção das máximas pode ser descrita da seguinte forma:

(13) Uma sílaba que leva o acento da palavra numa palavra polissilábica é uma máxima, se ela é precedida e seguida por uma sílaba com menos acento no mesmo verso. $^{29}$

Assim, as regras se aplicam para formar a nova linha de grade 2 até se chegar a um único asterisco, linha 3 :

(14) Minha terra tem palmeiras

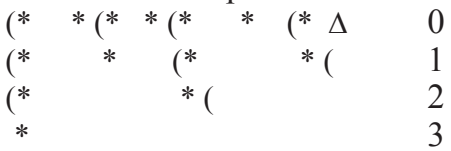

${ }^{27}$ No final da grade, "sobrou" um elemento à direita, que não foi fechado por um parêntese, porque não era possível mais repetir o padrão de iteratividade e, assim, formar um grupo. Ver (15) a. mais à frente.

${ }^{28}$ Ver Silva Ramos (1959, p. 23-32).

${ }^{29} \mathrm{Na}$ seção seguinte, discutiremos esse conceito. 
Dessa forma, a regra de iteratividade que descreve o exemplo (14) é a seguinte (adaptada da regra do tetrâmetro trocaico de F\&H, p. 22):

(15) Regras para o heptassílabo em português:

a. Linha de grade 0: começando da margem esquerda (E), insira um parêntese esquerdo (E), forme grupos binários, com cabeças esquerdas (E). O grupo formado depois da última iteração deve ser incompleto.

b. Linha de grade 1: começando da margem esquerda (E), insira um parêntese esquerdo (E), forme grupos binários, com cabeças esquerdas (E) ${ }^{30}$

c. Linha de grade 2: começando da margem esquerda (E), insira um parêntese esquerdo (E), forme grupos binários, com cabeças esquerdas (E).

Para que um verso seja bem formado, deve restar apenas um único asterisco na grade final, índice de que não há mais possibilidades iterativas de agrupamento. $\mathrm{O}$ que nos leva a elencar mais uma regra da teoria:

(16) A linha de grade mais abaixo numa grade bem formada deve conter exatamente um asterisco.

Por fim, a grade serve ainda para refletir a regulagem do tamanho dos versos gerada pelos agrupamentos da grade. Uma vez que em (14) os grupos nas três linhas de grade $(0,1,2)$ são binários (compostos de dois asteriscos), o tamanho máximo de um verso nesse metro (trocaico tetrâmetro) é dois vezes dois vezes dois (menos um, já que o último grupo da linha 0 é unitário), o que é igual a sete sílabas (ao mesmo tempo que é igual a um único asterisco na linha 3 , sem agrupamento).

Além de restringir o tamanho do verso, a grade ainda cria colunas com mais ou menos asteriscos. A coluna com mais asteriscos identifica a "cabeça" do verso como um todo. Em todos os exemplos acima, as sílabas projetadas a partir da linha 1 eram sempre sílabas proeminentes, ou "acentuadas", nos versos portugueses - o que não necessariamente é uma regra na teoria. Como todas as sílabas na linha 1 , por exemplo, são acentuadas, a coluna com mais asteriscos, que denota a "cabeça" do verso, indica aquela sílaba de maior importância na marcação do ritmo em determinado metro.

Para F\&H, os poetas compõem seus versos selecionando sequências de sílabas que se encaixam nas grades bem formadas de cada metro, rejeitando sequências que não reflitam essa boa formação métrica. Da mesma forma, os leitores dessa poesia percebem isso. Ou seja, as grades e as condições para sua formação são o que definem um verso, tanto para o poeta quanto para o leitor. Porém, F\&H fazem uma ressalva:

${ }^{30} \mathrm{O}$ parêntese à direita indica o fechamento do último grupo formado. No caso da linha 0 anterior, como a última iteração é incompleta, não ocorre o fechamento do grupo com o parêntese. 
Dizendo isso, entretanto, não estamos afirmando que poetas e seus leitores projetem asteriscos e insiram parênteses da maneira esquematizada acima. As grades métricas apresentam um meiopelo qual a boa formação dos versos poderia ser determinada. ${ }^{31}(2008$, p. 9)

A abordagem de F\&H permite pensar o metro de um verso a partir de uma perspectiva diversa daquela métrica tradicional. Metricistas, em várias épocas, se empenharam em formular leis e normas de cada tipo de verso, como se cada verso possuísse um tipo de fórmula que precisava ser seguida - de certa maneira quase mecânica. ${ }^{32}$ Ao passo que a nova teoria do metro poético de F\&H entende cada verso como uma representação fonológica da qual se destaca outra representação fonológica cuja organização silábica cria padrões reconhecíveis por nossos ouvidos e nosso cérebro, padrões esses que distinguem determinadas sucessões de fonemas, sílabas e acentos (além de todos os outros dados da fala) e as categorizam como poesia ou não. E a partir desse entendimento é possível pensar numa "grade" abstrata e separada do verso que explicita essa organização reconhecível como poesia, a mesma grade que é ilustrada por meio dos asteriscos e parênteses.

Assim, apresentada brevemente a teoria de F\&H, passaremos a aplicá-la a um verso da tradição poética da língua portuguesa muito caro e importante, o decassílabo.

\section{APLICAÇÃO DA TEORIA DE F\&H AO DECASSÍLABO PORTUGUÊS}

\subsection{Questões}

Tradicionalmente assume-se que o verso decassílabo como conhecemos hoje, também chamado de "heroico", foi introduzido na tradição métrica portuguesa na primeira metade do séc. XVI, a partir do verso italiano. ${ }^{33}$ Sá de Miranda (1487$1558)^{34}$ é considerado o primeiro a importar o endecasillabo italiano para a poesia de língua portuguesa, por volta de 1530, depois de uma viagem à Itália, e a ele é creditado promover uma renovação literária em Portugal naquela época. ${ }^{35}$ Sua influência decisiva verifica-se na poesia de Luís de Camões (1524-1580), posteriormente o grande responsável pela difusão e sucesso desse tipo de verso em língua portuguesa. Os mais de oito mil versos d'Os Lusíadas e quase toda lírica de Camões foram escritos em decassílabos segundo o modelo italiano introduzido em Portugal por Sá de Miranda.

31 "In saying this, however, we are not asserting that poets and their readers project asterisks and insert parentheses in the manner sketched just above. The metrical grids present one way in which the well-formedness of lines might be determined."

${ }^{32}$ Castilho (1851, p. 45) chega a ensinar os jovens a comporem versos sem sentido, apenas pela justaposição de palavras com acentuação predeterminada.

${ }^{33} \mathrm{E}$, em algum grau, também pelo contato com a poesia espanhola, que, por sua vez, também incorporava o endecasillabo italiano. Juan Boscán (1492-1542) e Garcilaso de la Vega (1503-1536) são tradicionalmente considerados os grandes propagadores do metro italiano em Espanha, por volta de 1530; e Santillana (1398-1458), o introdutor da "novidade" italiana, quase cem anos antes.

${ }^{34}$ Cf. Machado (1929).

${ }^{35}$ Para uma ótima apresentação da discussão histórica sobre a introdução da tradição italiana na poesia lusitana, ver Carneiro (1895). 
Tratados de versificação da língua portuguesa, então, desde as primeiras sistematizações, de Nunes (1615) e Guerreiro (1784), passando por Castilho (1851) e Bilac \& Passos (1905), até Pimenta (1927) e Carvalho (1965 [1941]), são programaticamente econômicos ao tratar do decassílabo. ${ }^{36}$ Esses tratados, de um modo geral, identificam o decassílabo diretamente como "italiano" ou "heroico" e apresentam dois modelo básicos de acentuação: 6-10 e 4-8-10, que seriam derivados de modelos italianos. ${ }^{37}$ Com pausa obrigada na $10^{\mathrm{a}}$ sílaba, o verso com outra pausa obrigada na $6^{a}$ é chamado propriamente "italiano" ou "heroico"; e o verso com pausas, além da $10^{\mathrm{a}}$, na $4^{\mathrm{a}}$ e $8^{\mathrm{a}}$ sílabas, é denominado de "sáfico". Mesmo quando mencionam ainda a influência de certo verso decassílabo provençal (com acento na $7^{\mathrm{a}}$ sílaba, 4-7-10), esses manuais se prendem, na maior parte das vezes, a elencar possibilidades acentuais consagradas ou desejadas apenas do metro heroico (6-10) e do sáfico (4-8-10). ${ }^{38}$

A partir do início do séc. XX pesquisas sobre a tradição métrica do português e ainda sobre a tradição poética europeia derivada da poesia latina rítmica se intensificam. ${ }^{39}$ Porém, só por volta da década de 1950 começam a aparecer trabalhos mais específicos sobre a tradição do decassílabo em língua portuguesa. Apesar do ceticismo de alguns, ${ }^{40}$ essas novas pesquisas indicam que o decassílabo na tradição poética portuguesa remonta a uma data muito anterior à da "novidade" do endecassillabo de Dante e Petrarca trazida à Lisboa pelo poeta mirandino. ${ }^{41}$

No Brasil, um dos primeiros a defender a múltipla e antiga tradição do decassílabo em língua portuguesa é Said Ali (1948), mesmo que de forma muito abreviada. ${ }^{42}$ Azevedo Filho (1962), tentando completar uma lacuna no estudo da métrica de língua portuguesa, apresenta um ótimo e detalhado panorama do desenvolvimento do verso de dez sílabas desde o latim rítmico medieval, que começa a abandonar a métrica quantitativa e assume a intensidade acentual como elemento rítmico principal, em tese apresentada para concorrência à cátedra de Língua Portuguesa da então Universidade da Guanabara, intitulada "O Verso Decassílabo em Português". De forma sinótica, apresento aqui o caminho histórico de desenvolvimento do decassílabo na poesia portuguesa traçado na obra do professor Leodegário Amarante: ${ }^{43}$

${ }^{36}$ Azevedo Filho (1971, p. 109-110) atribui apenas "valor histórico" à maioria desses tratados.

${ }^{37}$ Diversas vezes aqui usaremos essa notação para tratar da acentuação do verso: os números separados por hifens indicam a posição das sílabas tônicas no verso.

${ }^{38}$ Ver Apêndice 1, p. 36.

${ }^{39}$ Ver Diez (1863), Mussafia (1896), Thomas (1904) e, com grande foco na transição do latim, Beare (1956).

${ }^{40}$ Cf. Chociay (1974, p. 104).

${ }^{41}$ A bibliografia é vasta, mas vale citar: Burger (1957), Le Gentil (1953) e Saavedra Molina (1946). Spina (2003 [1971], p. 49) fala de um decassílabo do séc. X-XI na França e encontrado na Itália no séc. XII (1135).

${ }^{42}$ Mesmo em Portugal, dentre os manuais a que tivemos acesso, apenas Pimenta (1928) e Carvalho (1965 [1941]) se referem à versificação trovadoresca anterior à Sá de Miranda e Camões, e mesmo assim não relacionam as duas tradições. Pelo contrário, Carvalho (p. 148-155) defende a ideia de naturezas rítmicas completamente diferentes (musicais versus acentuais) entre o verso trovadoresco/ medieval e o clássico.

${ }^{43}$ Azevedo Filho ainda descreve os padrões rítmicos ou acentuais de cada tradição, sempre por meio de exemplos. 


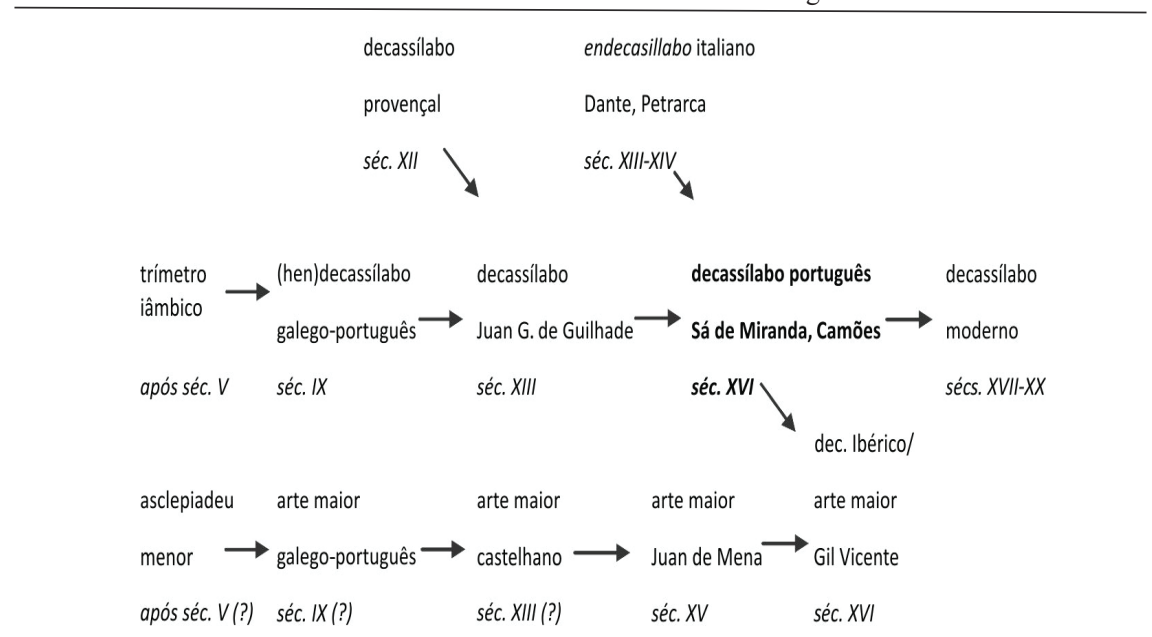

Said Ali (1999 [1948], p. 85) ensina: "A literatura portuguesa conhece três espécies de hendecassílabos: o provençal, o ibérico e o italiano". O decassílabo provençal (com acentuação na $7^{a}$ sílaba) não teria se popularizado, mas teria influenciado a poesia cortesã galego-portuguesa dos sécs. XII-XIII. O decassílabo ibérico, na verdade, seria a variação do verso de arte maior de tradição hispânica (com acentuação na $5^{\mathrm{a}}$ sílaba), cujo uso foi mais notável em Gil Vicente. Sendo o italiano o modelo incorporado à tradição métrica portuguesa a partir do séc. XVI com mais sucesso. O breve testemunho de Said Ali ajuda a explicar o quadro montado anteriormente a partir de Azevedo Filho (1962).

Embora esse cenário de desenvolvimento histórico seja controverso, ${ }^{44}$ essa apresentação se fez necessária para situar o decassílabo que será nosso objeto de estudo. Para fugir de discussões diacrônicas talvez sem solução, tratarei aqui dos decassílabos que se fixaram em nossa tradição poética, que, em grande parte, foram tomados a partir do modelo italiano, e para isso, utilizarei um exemplário da tradição métrica dos séculos XVI a XIX. ${ }^{45}$

Outro problema, embora pequeno, é o próprio nome do verso. Apesar de, modernamente, ser usual e comum a denominação de "decassílabo" para o verso que estudamos aqui, e conste esse nome da maioria dos manuais de versificação em língua portuguesa, o verso d'Os Lusíadas é ostensivamente um verso de onze sílabas. Said Ali (1999, p. 19-20) indica que 94\% dos 8816

${ }^{44}$ As influências poéticas muitas vezes podem ter sido interdependentes ou simplesmente coincidências de acentos não significam influências de uma tradição poética sobre a outra. Por exemplo, um certo decassílabo provençal do séc. X (do poema de Boécio) pode ter influenciado o próprio decassílabo italiano, cf. Spina (2003, p. 46-7).

${ }^{45}$ Obviamente, começamos com os versos do séc. XVI, de Sá de Miranda e Camões. Embora, consideremos também Gregório de Matos (séc. XVII) e Claudio Manoel da Costa (séc. XVIII), nosso interesse se desloca para a observação dos decassílabos do início do séc. XIX, seu período último de desenvolvimento "clássico". Do Romantismo em diante, o decassílabo vai sofrer o impacto de novas perspectivas estéticas, que não discutiremos aqui. 
versos do épico lusitano são versos de 11 sílabas e, assim, defende que tal verso deva ser chamado de "hendecassílabo", como, inclusive, era chamado originalmente. A confusão da nova nomenclatura de "decassílabo" no lugar de "hendecassílabo", para Said Ali, começara com o Tratado de Metrificação, de António Feliciano Castilho, em 1851, ${ }^{46}$ influenciado pelos manuais de métrica franceses. No francês, faria mais sentido chamar esse verso de "decassílabo" porque a língua possui um padrão de acentuação agudo, não grave como o português, ou seja, a última sílaba gramatical do verso coincide naturalmente com a última sílaba métrica. Numa língua predominantemente grave, ou seja, paroxítona, a última sílaba do verso normalmente recai na penúltima sílaba gramatical, assim, a maioria dos versos "decassílabos" em português, tem onze sílabas (embora haja decassílabos com 10 e 12 sílabas). Defendendo que se trata, pois, de um erro chamar o verso do soneto camoniano de "decassílabo", Said Ali, em 1948, adota o "hendecassílabo". Aqui, evitarei a discussão, e tratarei tradicionalmente este tipo verso como "decassílabo", embora concorde com Said Ali. ${ }^{47}$

Seja como tenha sido a evolução do decassílabo em português é fato que a acentuação italiana foi preferida após Sá de Miranda e Camões. Tanto Gregório de Matos (séc. XVII) como Claudio Manuel da Costa (séc. XVIII), Álvarez de Azevedo (séc. XIX) e Olavo Bilac (séc. XIX-XX), apenas para citar o nome de um autor representativo de cada época, cultivaram o verso heroico ora intercalado com o sáfico e abandonaram gradativamente outras acentuações. ${ }^{48}$ Muito embora não haja um trabalho ${ }^{49}$ que quantifique esse corpus, como, por exemplo, há em espanhol e italiano. ${ }^{50}$

A tratadística sobre a métrica da língua portuguesa se divide em visões ora estritas (e quase normativas) ora amplas demais. Castilho (1851) e Bilac \& Passos (1905), duas grandes obras que influenciaram sobre maneira a arte poética portuguesa, elencam de forma sumária poucos cânones do decassílabo:

${ }^{46}$ Junto com Castilho (1851), também Bilac \& Passos (1905), Duque-Estrada (1914), Proença (1955), e Mattoso (2010), em seus tratados de versificação, anotam "decassílabo". Azevedo Filho (1971, p. 110) lembra que foi Couto Guerreiro o primeiro a adotar a contagem francesa, embora tenha sido Castilho realmente quem consagrou este tipo de contagem de sílabas. Cf. Guerreiro (1784, p. 6-7).

${ }^{47}$ Utilizar a nomenclatura "hendecassílabo" também proporciona um estreitamento científico maior com a literatura internacional sobre o tema, que chama endecassilabo, em italiano, endecasílabo, em espanhol, hendécasyllabe, em francês, e hendecasyllabe, em inglês. Azevedo Filho (1971) também recrimina a "reforma" de Castilho.

${ }^{48}$ Para um pequeno quadro estatístico da acentuação dos versos portugueses, ver Apêndice 2, p. 37.

${ }^{49}$ Não consegui encontrar nenhum trabalho em língua portuguesa ou em outra língua que quantifique padrões métricos de significativo corpus do verso português, mesmo porque os tratados até meados do séc. XX se restringiam a contar a acentuação 6-10 (heroica) ou 4-8-10 (sáfica). O único que faz algo parecido é Macambira (1983, p. 95), mas mesmo assim só analisa 198 versos e se vale de uma escansão muito particular, valendo-se da ideia de uma acentuação peônica do decassílabo.

${ }^{50}$ Sobre uma análise ampla e completa sobre o metro espanhol, cf. Navarro (1973). Já Saavedra-Molina (1946) análise e traz estatísticas de acentuações preferidas em aproximadamente dez mil versos, dos sécs. XV a XX. 


\begin{tabular}{c|c} 
Castilho & Bilac \& Passos \\
\hline $6-10$ & $2-4-8-10$ \\
$4-8-10$ & $2-4-6-10$ \\
$2-4-6-8-10$ & $1-3-6-10$ \\
$2-6-8-10$ & $2-4-6-8-10$ \\
$3-6-10$ & $3-6-10$ \\
$2-7-10$ & \\
$4-7-10$ &
\end{tabular}

Note como Bilac \& Passos desconsideram a acentuação provençal (na $7^{\mathrm{a}}$ sílaba). Por outro lado, Proença (1955), indica 28 possibilidades do decassílabo, embora só exemplifique 21. Chociay (1974) elenca as 28 possibilidades previstas por Proença para o decassílabo que ora apresento aqui: ${ }^{51}$

\begin{tabular}{ccc} 
Com 5 acentos & Com 4 acentos & Com 3 acentos \\
\hline $1-3-5-7-10$ & $1-3-6-10$ & $2-6-10$ \\
$1-3-5-8-10$ & $1-3-7-10$ & $3-6-10$ \\
$1-3-6-8-10$ & $1-4-6-10$ & $3-7-10$ \\
$1-4-6-8-10$ & $1-4-7-10$ & $4-6-10$ \\
$2-4-6-8-10$ & $1-4-8-10$ & $4-7-10$ \\
& $1-5-7-10$ & $4-8-10$ \\
& $1-5-8-10$ & \\
& $2-4-6-10$ & \\
& $2-4-7-10$ & \\
$2-4-8-10$ & $2-5-7-10$ \\
$2-5-8-10$ & \\
$2-6-8-10$ & $3-5-7-10$ \\
$3-5-8-10$ & \\
& $3-6-8-10$ & \\
& $4-8-10$ &
\end{tabular}

${ }^{51}$ Muitas dessas possibilidades rítmicas (além de 6-10 e 4-8-10) serão caras aos poetas durante o séc. XX e depois, especialmente, após o Simbolismo e dentro do Modernismo, porém, como advertimos, não serão objeto deste trabalho. 
Com tantos ou tão poucos padrões acentuais, o que, por princípio, definiria o metro decassílabo ${ }^{52}$ Nenhum do tratados consultados conseguiu dar respostas satisfatórias, quando sequer tentavam. Contudo, de certa maneira, há dois consensos, mesmo que explicitados de formas muito variadas: (1) a pausa obrigada ou acento principal na $10^{\mathrm{a}}$ sílaba, e (2) uma prototípica ou preferida alternância binária (iâmbica).

Meu objetivo é utilizar a teoria de F\&H para oferecer uma resposta que permita descrever o decassílabo além apenas de suas possibilidades concretizadas de realização, a ponto de demonstrar que algumas acentuações não conformam um metro decassílabo. E uma resposta para essa questão será a "grade métrica" do decassílabo, explicitada de acordo com a teoria de F\&H. Sem uma teoria como essa (ou como outras abordagens da métrica gerativa), os manuais tradicionais acabam caindo na armadilha de apenas listar possibilidades, opções, preferências ou padrões normativos. Mesmo Chociay é extremamente descritivo num trabalho que se propõe a discutir a teoria do ritmo. ${ }^{53}$

Por meio da distinção entre sílabas acentuadas e "máximas" será possível dar uma explicação para a grande variação acentual do decassílabo não tratando apenas de preferências, mas sim do princípio básico de reconhecimento da poesia: um padrão métrico - entendido por F\&H não como norma, mas sim como constituição fonológica em nível suprassegmental, de natureza constituinte própria e paramétrica. Visto como um verso de natureza iâmbica, cujo padrão acentual pressuporia apenas sílabas pares proeminentes, o decassílabo suporta até mesmo acentos em sílabas ímpares (veja os padrões 3-6-10 e 4-7-10). Por meio da criação das "grades métricas" dos decassílabos poderemos perceber que mesmo esses padrões ímpares podem constituir versos bem formados, de acordo com a teoria de F\&H. Os mesmos mecanismos de formação das grade métricas nos ajudarão a colocar alguns padrões de fora, entendendo-os como "não-métricos", como será o caso do 3-7-10, que veremos ao final da próxima seção.

Como Piera (2008, p. 102) questiona acerca do verso espanhol, podemos nos perguntar igualmente em português: por que um verso decassílabo aceitaria acento na $3^{\mathrm{a}}$ sílaba e não na $5^{\mathrm{a}}$ (sem ser acentuado na $6^{\mathrm{a}}$ )? Isso poderá ser explicado com a noção de "máxima". Bem como, acrescento, a noção de máxima ajuda a explicar a recorrente a acentuação na $1^{\mathrm{a}}$ sílaba de vários padrões métricos do decassílabo, sem contrariar sua natureza iâmbica.

Então, vejamos como a teoria de F\&H pode explicar essas questões.

\footnotetext{
${ }^{52}$ Saavedra-Molina (1946), apenas para os modelos com acentuação preponderante na $4^{\mathrm{a}}$ e na $6^{\mathrm{a}}$ sílabas, identifica mais de 60 padrões acentuais para o decassílabo. Couto Guerreiro (1784), por outro lado, só reconhece o heroico.

${ }^{53}$ Chociay chega ao ponto de tratar da "receita tradicional dos decassílabos" e propor um modelo de estruturação 6-10 e 4-10 supostamente opostos, baseado na equivalência $2^{\mathrm{a}}-8^{\mathrm{a}}$, o que não se sustenta tendo em vista as acentuações comuns na $1^{\mathrm{a}}$ e na $3^{\mathrm{a}}$.
} 


\subsection{Aplicação}

Para tratar do decassílabo do português, seguirei aqui o modelo que Piera (2008, p. 94-132) (daqui para em diante citado simplesmente como Piera), utilizou para tratar do metro endecasílabo espanhol no capítulo 4, intitulado "Southern Romance" ("As línguas neolatinas do sul"), do livro de F\&H. Em relação à exposição de Piera acerca do endecasílabo espanhol, pretendo alargar o conceito de máxima no metro português, mas trabalhar com a mesma distinção de máximas e sílabas acentuadas. Embora o decassílabo português e espanhol compartilhem características comuns, poderemos ver que os poetas portugueses aprovaram outras variações de acentuação que o metro permitia: a acentuação da $1^{\mathrm{a}}$ sílaba e a acentuação extrarrítmica na $5^{\mathrm{a}}$ ou na $7^{\mathrm{a}}$ sílaba, que farão sentido quando diferenciamos sílabas acentuadas de máximas. ${ }^{54}$

Um dos primeiros pontos que precisam ser esclarecidos é que, diferente da métrica inglesa, a tradição métrica em língua portuguesa (assim como a espanhola) não "conta" certas sílabas de forma regular, como as sílabas em sinalefa ${ }^{55}$ e as sílabas após a última tônica do verso. O que mesmo para aqueles pouco versados nas artes métricas da nossa língua é algo mais ou menos simples - qualquer instrução básica da metrificação portuguesa ensina essas regras. Os manuais tratam desse processo desde sempre de maneira formal e descritiva, até, por vezes, com tons normativos. Podemos explicar essa "não contagem" de sílabas nos termos da teoria de F\&H com as seguintes regras de sílabas "não-projetáveis":

(17) Não-projeção da vogal

Numa sequência de duas vogais consecutivas separadas por limite de palavra:

a. A segunda vogal não é projetada para a linha de grade 0 , se a primeira é acentuada. Logo a primeira é projetada.

b. Fora disso, a primeira vogal não é projetada para a linha de grade 0 , e sim a segunda.

(18) Não-projeção de fim de verso

a. Se a palavra mais à direita num verso contém uma sílaba acentuada, não projete enhuma sílaba à direita dessa sílaba acentuada.

b. Se a palavra mais à direita num verso não contém uma sílaba acentuada, não projete nenhuma sílaba à direita da sílaba inicial da palavra mais à direita. ${ }^{56}$

\footnotetext{
${ }^{54}$ Para uma escansão completa dos poemas utilizados como fonte e que geraram os números do Apêndice 2, acessar http://www.uff.br/lingualatina/poesia/decassilabos.

${ }^{55}$ Sinalefa (ou sinafia) ou elisão é o fenômeno da queda da vogal final de uma palavra quando a palavra seguinte começa por vogal no verso.

${ }^{56}$ Por serem muito raros na poesia portuguesa (e na poesia espanhola e italiana), vamos evitar usar como exemplo versos que não contenham a última palavra acentuada. Assim, a regra $18 b$ não será utilizada aqui.
} 
Por se tratar de teoria derivacional baseada em regras, é necessário que as regras sejam bem definidas e válidas para todos os casos, assim, podemos melhorar a definição da regra (10) agora: ${ }^{57}$

(19) Projete cada sílaba como um asterisco para formar a linha de grade 0, com exceção das sílabas enquadradas pelas regras 17 e 18. Indique estas sílabas com o simbolo $\Delta$ (delta).

Aplicando então a regra (19) ao verso de Duque-Estrada abaixo, por exemplo, chegamos à seguinte grade:

(20) Brilhou no céu da pátria nesse instante

(Hino Nacional, Duque-Estrada)

As sílabas finais -se e -te (de "nesse" e "instante") não se projetam para a linha de grade 0 . Para marcar a não-projeção utiliza-se o símbolo $\Delta$ (delta). No caso de nes-s(e), a primeira vogal não é projetada porque se trata de uma vogal em sílaba final seguida de vogal inicial da palavra seguinte não acentuada (regra 17b). Já o -te de "instan(te)" não se projeta de acordo com a regra (18).

(21) "Revive Afonso acaso! É este o Tejo? $* * \Delta * * \Delta * * * * \Delta \Delta * * \Delta$

(Niterói, Januário Barbosa)

No caso de " $E$ (e)ste", agora a vogal que não se projeta é a segunda (regra 17a). De novo, em "Reviv(e) Afonso" e "Afons(o) acaso" aplica-se a regra 17b, que a regra mais comum de não-projeção nos verso em português. E, como não contamos as sílabas pós-tônicas em fim de verso, em " $T e(j o)$ ", aplicamos a regra 18 e não projetamos sua última sílaba.

Com exceção de sílabas enquadradas nas regras acima (17 e 18), todas as demais sílabas devem ser projetadas para a formação da linha de grade 0 , de acordo agora com a regra (19).

A partir das projeções e da linha grade 0, podemos seguir adiante. E o próximo passo é identificar os grupos, inserindo parênteses segundo uma regra de iteratividade:

(22) Brilhou no céu da pátria nesse instante

$* \quad *) \quad * *$ ) $\quad * \quad *) * \quad *) \Delta * \quad *) \Delta \quad 0$

(23)“'Revive Afonso acaso! É este o Tejo?

$* *) \Delta * *) \Delta * *) * * \Delta) \Delta * *) \Delta$

A regra de iteratividade para a identificação dos grupos na linha de grade 0 do decassílabo é a mesma do espanhol e do pentâmetro inglês: ${ }^{58}$

\footnotetext{
${ }^{57}$ Em itálico, adiciono as condições 17 e 18 à regra (10) de $\mathrm{F} \& H$ pois essas condições são muito regulares na métrica do português, diferentemente da poesia inglesa.

${ }^{58}$ Cf. Piera (2008, p. 102-3).
} 
(24) Linha de grade 0: começando da margem direita (D), insira um parêntese direito (D), forme grupos binários, com cabeças direitas (D).

Esse agrupamento básico como observamos em (22) e (23) denota marcadamente a natureza iâmbica no metro românico. ${ }^{59} \mathrm{~A}$ linha de grade 0 é gerada assim para qualquer padrão bem formado do metro decassílabo. A partir da montagem da linha de grade 0 , projetamos a linha de grade 1. E, para tanto, precisamos respeitar duas regras muito importantes:

(25) Projete a cabeça de um grupo para a próxima linha.

(26) Máximas devem ser projetadas para a linha 1.

Então agora, precisaremos apresentar e comentar o conceito de máxima. Para o inglês, F\&H (p. 47) apresentam:

(27) A sílaba que leva o acento de uma palavra polissilábica é uma máxima, se ela for imediatamente precedida e seguida por sílabas menos acentuadas no mesmo verso.

De acordo com Piera (p. 104), a definição de máxima para a poesia espanhola seria um pouco mais restrita, o que se torna importante para sua explicação:

(28) A sílaba que leva o acento de uma palavra é uma máxima, se ela for imediatamente precedida e seguida por sílabas átonas no mesmo verso.

Piera adota essa definição de forma empírica por meio da observação da não ocorrência de máximas na $5^{\mathrm{a}}$ sílaba e pela possibilidade de controle da posição dos monossílabos tônicos. ${ }^{60}$ Porém, em português, precisaremos entender máximas de forma mais ampla, como no inglês:

(29) A sílaba que leva o acento de uma palavra é uma máxima, se ela for imediatamente precedida e seguida por sílabas menos acentuadas no mesmo verso.

A importância dessa definição mais ampla de máximas no português se verifica quando precisamos explicar a acentuação de versos com acentos na $6^{\mathrm{a}}$ e na $7^{\mathrm{a}}$ sílaba, ${ }^{61}$ como em (30) e (31), versos de sonetos de Claudio Manoel da Costa:

(30) A quem posso porém nisso ofender?

(31) Para cantar de amor tenros cuidados,
3-6-10, não 3-6-7-10

4-6-10, não 4-6-7-10

\footnotetext{
${ }^{59}$ Outros estudos gerativos associam os decassílabos (italianos, espanhóis e portugueses) ao iambic pentameter do inglês, como Nespor \& Vogel (1986) e Hanson (1996).

${ }^{60}$ Não vamos aprofundar a discussão aqui.

${ }^{61} \mathrm{E}$ também os casos de acento na $5^{\mathrm{a}}$ e na $6^{\mathrm{a}}$ sílabas. 
A distinção entre sílabas acentuadas e máximas faz com que o verso possa continuar tendo a $6^{\mathrm{a}}$ sílaba como máxima, embora haja acento na $7^{\mathrm{a}}$ sílaba, evitando-se assim uma acentuação estranha como 3-6-7-10 ou 4-6-7-10. ${ }^{62}$

Regularmente as tradições poéticas evitam o "choque de acentos" e os tratados de métrica muitas vezes apontam essa particularidade como uma atenuação do acento não preferencial nesses casos. A teoria ajuda a explicar a natureza diversa das duas sílabas: sendo uma (a $6^{\mathrm{a}}$ ) acentuada e máxima, e a outra $\left(7^{a}\right)$, acentuada não máxima. Essa distinção é importante na hora de montar as grades métricas do verso.

Antes ainda de avançarmos, vejamos também que, com o conceito de projeção de máximas, podemos explicar a regra (24) de iteratividade da linha de grade 0: se tentarmos formar a grade 0 no sentido inverso, vamos ter problemas: não vamos conseguir projetar as máximas para a linha de grade 1, como em (32), e assim estaríamos despeitando a regra (26):

(32) Ícaro me põe medo, e Lucifer!

$\begin{array}{cccccc}* *(* & * & * & *(\Delta * & *(* *) & 0 \\ * & * & * & * & * & 1\end{array}$

(Sá de Miranda)

Nesse caso, de agrupamentos com cabeças esquerdas, deixamos de projetar para linha 1 a $6^{\mathrm{a}}$ sílaba, que, sendo uma máxima, devia ser projetada. Na tentativa de projetar a $6^{\mathrm{a}}$ sílaba, poderíamos tentar começar os agrupamentos a partir de um asterisco para dentro, porém, dessa forma, vamos manter desagrupada uma sílaba recorrentemente acentuada na nossa tradição métrica, a $1^{\mathrm{a}}$ sílaba, colocando como cabeça do verso uma sílaba não acentuada:

(32a) Ícaro me põe medo, e Lucifer!

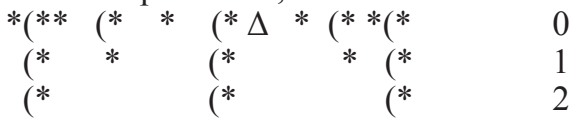

Definidas, então, as regras de não-projeção (17) e (18), a regra de iteratividade para agrupamento da linha de grade 0 (24), as regras de projeção das sílabas (25) e máximas (26) e definido o conceito de máxima para a projeção da linha de grade 1 (29), podemos então derivar as grades do metro decassílabo.

Assim como Piera, partirei de um cânone dos padrões do decassílabo. Embora o português não conte com um cânone tão bem estabelecido como o espanhol. Julgo que a lista apresentada por Said Ali (1999) é a melhor para servir como ponto de partida, porque inclui os padrões do verso italiano mais usuais, não recorrendo a simplificações normativas ou preferências poéticas. Said Ali apresenta 8 possibilidades do metro italiano, desconsiderando o provençal e o ibérico: ${ }^{63}$

\footnotetext{
${ }^{62}$ Sobre a acentuação extrarrítmica do endecasillabo de Petrarca, ver Piera (2008, p. 111-5).

${ }^{63}$ Said Ali lista as possibilidade usando numeradores (I, II, III...), por questões práticas, como evitar confusão com a notação de Piera (i, ii, iii...), adotei uma ordenação por letras (A, B, C...).
} 


\begin{tabular}{c|c} 
& Said Ali $^{64}$ \\
\hline A & $2-4-6-8-10$ \\
\hline B & $2-6-8-10$ \\
\hline C & $3-6-8-10$ \\
\hline C1 & $1-3-6-8-10$ \\
\hline$D$ & $1-6-8-10$ \\
\hline E & $1-4-6-8-10$ \\
\hline F & $1-4-8-10$ \\
\hline$G$ & $2-4-8-10$
\end{tabular}

Meu objetivo agora será criar um paralelo entre os modelos de endecasílabos espanhóis proposto por Piera (p. 103-9) e os padrões de Said Ali, utilizando os pressupostos da teoria de $\mathrm{F} \& \mathrm{H}$, muitos deles vistos até aqui. Vejamos as regras para o decassílabo padrão (i) 2-6-10, de Piera:

(33) Regras para o decassílabo - padrão (i) 2-6-10:

a. Linha de grade 0: começando da margem direita (D), insira um parêntese direito (D), forme grupos binários, com cabeças direitas (D).

b. Linha de grade 1: começando da margem esquerda (E), insira um parêntese esquerdo (E), forme grupos binários, com cabeças esquerdas (E). O último grupo (mais à direita) deve ser incompleto (unitário).

c. Linha de grade 2: começando da margem esquerda (E), insira um parêntese esquerdo (E), forme grupos binários, com cabeças esquerdas (E). O último grupo (mais à direita) deve ser incompleto (unitário).

d. Linha de grade 3: começando da margem esquerda (E), insira um parêntese esquerdo (E), forme grupos binários, com cabeças esquerdas (E).

Essa é a regra do padrão que, não à-toa, é enumerada como (i). Dela serão derivadas as regaras de vários outros modelos. Em português, a acentuação (A) 2-4-6-8-10 (ou sua variante 2-4-6-10) é uma das mais comuns, se não a mais comum. A acentuação na $8^{\mathrm{a}}$ sílaba não trará nenhuma alteração para as grades, configurando-se como variação de quase todos os metros, já que sendo máxima ou não, ela sempre se projeta para a linha 1 , mas não tem necessidade de se projetar para a linha 2. Vejamos como a regra (33) se aplica completamente ao padrões (A) de Said Ali: 
(A) 2-4-6-8-10

Cobriram reinos, ilhas, cabos, brenhas.

(Niterói,Januário Barbosa) ${ }^{65}$

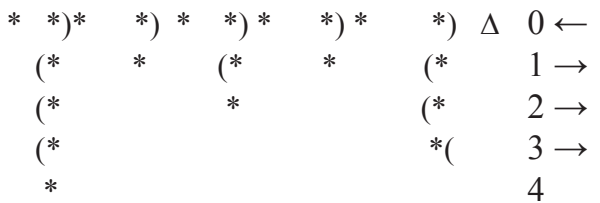

2-4-6-10

Que ao céu com mão soberba arremessara

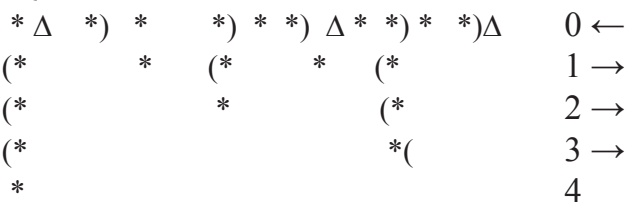

O padrão (B) se distingue do anterior apenas pela acentuação na $4^{\mathrm{a}}$ sílaba, mas respeita também à regra (33), desde que a segunda e a sexta posições sejam ocupadas por uma máxima. Em todos os casos dos padrões (A) e (B), uma espécie de padrão-base se projeta na linha 2:66

(B) $2-6-8-10$

Nos braços maternais, nascido apenas,

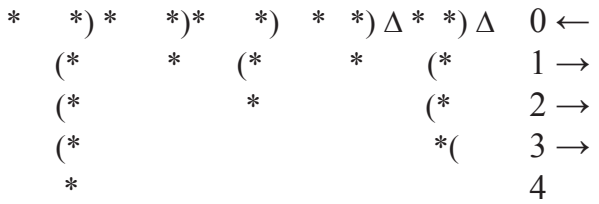

2-6-10

Ferido pelo ferro, com que Marte

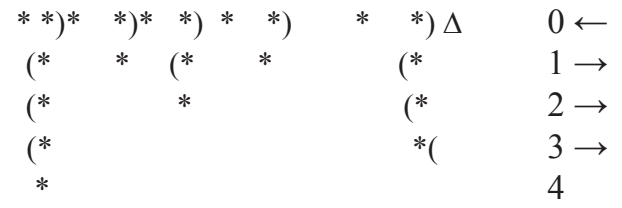

${ }^{65}$ Todos os demais exemplos sem indicação de fonte são provenientes do poema Niterói, de Januário da Cunha Barbosa. Para acesso digital à edição atualizada do poema, acessar: http://www.uff. br/lingualatina/nicteroy.

${ }^{66}$ Cf. Piera (p.105). 
Para explicar o padrão (C) 3-6-10, precisamos recorrer a um regra especial da teoria que no metro da língua portuguesa será muito recorrente: a regra de apagamento (deletion rule), aqui descrita da seguinte forma: ${ }^{67}$

(34) Apague o asterisco da linha de grade 0 da sílaba que se projeta para a cabeça do verso.

(35) Apague o asterisco da linha de grade 1 da sílaba que se projeta para a cabeça do verso.

Antes de enfraquecer a teoria com exceções e regras condicionais, F\&H propõem um pequeno conjunto de regras de apagamento que ajudam a explicar certas conformações acentuais, em termos da formação de uma grade métrica. Note que uma regra de apagamento só pode ser aplicada na posição da cabeça do verso. Essa característica, na verdade, expande o valor da posição de cabeça de verso, pois esta seria a única posição capaz de sofrer alterações e permitir a formação de grades intermediárias.

Para o padrão (C), aplicamos as regras do padrão (i) 2-6-10 e depois as regras de apagamento (35) e (34), nesta ordem para esse padrão. Uma regra de apagamento só pode ser aplicada no grupo de onde se projeta a cabeça do verso - por isso, neste caso, é aplicada primeiro na linha 1, o que altera a posição da cabeça do verso, podendo ser aplicada depois na linha 0 :

(C) 3-6-8-10

Do sepulcro do sol, erguida há pouco,

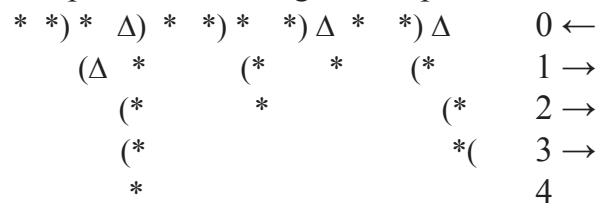

3-6-10

A flamígera Lemnos, arrancada

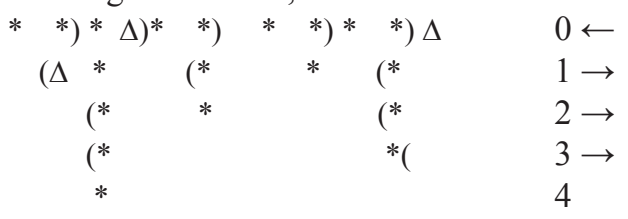

${ }^{67}$ Para maiores explicações sobre as regras de apagamento, ver F\&H, 1.8. Verdadeiramente, a existência dessas regras carece de mais explicação. A propósito, cito F\&H: "The cognitive status of such intermediate grids is not well understood at this time, but our present ignorance about intermediate representations does not impugn their status. [...] It is far more likely that as cognitive science advances, such representations will be fully integrated into the theory." (2008, p. 32). [O status cognitivo dessas grades intermediárias não é bem compreendido nesse momento, mas nossa presente ignorância sobre essas representações intermediárias não impugna o status delas. [...] É muito provável que, à medida que a ciência cognitiva avance, tais representações sejam integradas completamente à teoria.] 
Said Ali apresenta como variante do padrão (C) o padrão (C1). Aqui, o conceito de máxima versus sílaba acentuada ajuda a explicar que ambas não deixam de se vincular ao mesmo padrão (3-6-8-10). Já que a primeira sílaba não pode ser máxima, uma vez que não é antecedida por nenhuma sílaba, logo não precisa ser projetada para a linha 1 , e assim podemos usar o mesmo modelo de grade de $(\mathrm{C})$ :

(C1) 1-3-6-8-10

Cinge a frente ao robusto altivo jovem

\begin{tabular}{|c|c|c|c|c|}
\hline$\Delta *)$ & $* \quad \Delta) \Delta$ & $* \quad *) \Delta *$ & $*) * *) \Delta$ & $0 \leftarrow$ \\
\hline$(\Delta$ & * & $(*$ & * $\quad(*$ & $1 \rightarrow$ \\
\hline & (* & $*$ & (* & $2 \rightarrow$ \\
\hline & (* & & $*($ & $3 \rightarrow$ \\
\hline & $*$ & & & 4 \\
\hline
\end{tabular}

$1-3-6-10$

Inda mádida e nova, inda ignorada

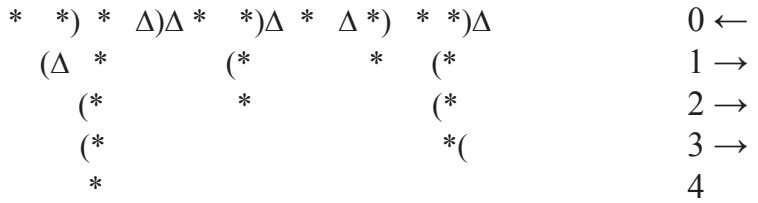

Para o padrão-base (ii) 4-8-10, Piera (p. 105) apresenta as seguintes regras, que agora são distintas, em parte, da regras (33), que aplicamos até agora:

(36) Regras para o decassílabo - padrão (ii) 4-8-10:

a. Linha de grade 0: começando da margem direita (D), insira um parêntese direito (D), forme grupos binários, com cabeças direitas (D).

b. Linha de grade 1: começando da margem esquerda (E), insira um parêntese esquerdo (E), forme grupos binários, com cabeças direitas (D). O último grupo (mais à direita) deve ser incompleto (unitário).

c. Linha de grade 2: começando da margem esquerda (E), insira um parêntese esquerdo (E), forme grupos binários, com cabeças direitas (D). O último grupo (mais à direita) deve ser incompleto (unitário).

d. Linha de grade 3: começando da margem esquerda (E), insira um parêntese esquerdo (E), forme grupos binários, com cabeças esquerdas (E).

Veja que as regras para as linhas 1 e 3 são as mesmas, e isso, segundo Piera (p. 104), vale para qualquer decassílabo. Esta regra (36) podemos aplicar ao que Said Ali indica como padrão $(\mathrm{G})$ : 
(G) 2-4-8-10

No choque horrível que, dos Flegros Campos,

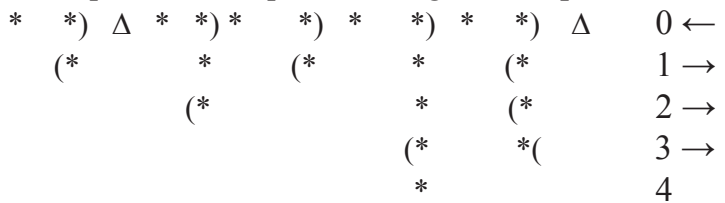

Said Ali vê (F) 1-4-8-10 como outro padrão. Porém, segundo a teoria de $\mathrm{F} \& \mathrm{H}$, podemos ver que se trata do mesmo metro com a variação da sílaba 1 , que mesmo sendo acentuada, não é máxima, logo, não precisa se projetar para linha 1:

(F) $1-4-8-10$

Surgem co' as águas, do tesouro oculto,

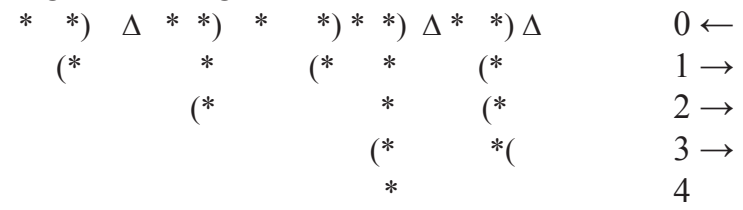

Said Ali não apresenta o padrão 4-7-10, por se tratar de um verso de influência provençal. Realmente, a acentuação 1-4-7 não se registra como um verso comum na tradição portuguesa, mas Castilho apresenta a variedade, assim como Bandeira (1964) e Azevedo Filho (1971), chamando o verso de "gaita galega" ou "muñieras". Vou demonstrá-lo conforme Piera no padrão (iii), aplicando a regra (36) e, em seguida, a regra de apagamento (34), a partir do modelo (G) e vou identificá-lo como $(\mathrm{H})$ :

(H) 4-7-10

As aves todas cantavam d'amores.

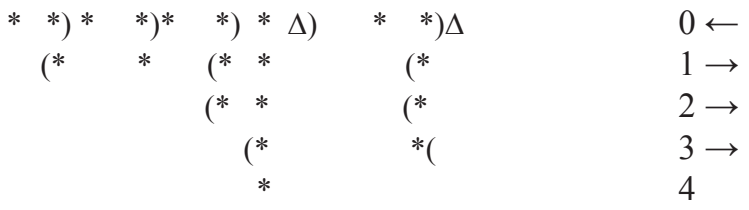

Castilho ainda aponta 2-7-10, mas se trata apenas da variação de 4-7-10, nenhuma vez registrada nos exemplos de que me vali, a que daremos pouca importância por ora. Para essa acentuação, precisamos nos valer da regra (37), conforme Piera (p. 108):

(37) No máximo uma das três sílabas projetadas na linha 2 pode ser não-acentuada. 
Vejamos no exemplo que identifico como (I):

(I) 2-7-10

A férrea e precipitada bigorna.

(In: Castilho, p. 39) ${ }^{68}$



Por último, temos os padrões (D) e (E), que são os dois variações do padrão (A). O padrão (D) se explica pelo padrão (vi) 1-6-10 de Piera, que aplica a regra (33) do padrão (A) e a regra de apagamento (34):

(D) $1-6-10$

Ícaro me põe medo, e Lucifer!

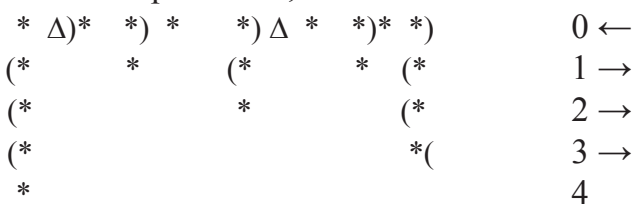

Já o padrão (E) se identifica com o padrão (iv) 4-6-10 de Piera, que aplica a mesma regra (33) do padrão e, em seguida, a regra de apagamento (35), em que a sílaba 1 pode ser acentuada sem variação no metro, já que não é máxima:

(E) $1-4-6-10$

Tomo entre vós, ó montes, o instrumento;

$\begin{array}{cccccccccc}* \Delta *) & * & * & * & * & * & \left.\Delta^{*}\right) & * & *) \Delta & 0 \leftarrow \\ (\Delta & * & (* & & * & (* & \\ & (* & * & & & (* & \\ & (* & & & & *( & \\ & * & & & & & 3 \rightarrow \\ & & & & & & \end{array}$

Assim, conseguimos estabelecer um paralelo com a exposição de Piera e propor o seguinte quadro de modelos para o decassílabo português, desde que o conceito de máxima seja mais abrangente do que no espanhol:

68 Não foi possível identificar a fonte do verso que Castilho cita. 


\begin{tabular}{c|c|c} 
& $\begin{array}{c}\text { Padrões do português } \\
\text { SAID ALI (1999) }\end{array}$ & $\begin{array}{c}\text { Padrões do espanhol } \\
\text { (PIERA, 2008) }\end{array}$ \\
\hline A & $2-4-6-8-10$ & padrão (i): 2-6-10 \\
\hline B & $2-6-8-10$ & padrão (i): 2-6-10 \\
\hline C & $3-6-8-10$ & padrão (v): 3-6-10 \\
\hline C1 & $1-3-6-8-10$ & padrão (v): 3-6-10 \\
\hline D & $1-6-8-10$ & padrão (vi): $1-6-10$ \\
\hline E & $1-4-6-8-10$ & padrão (iv): 4-6-10 \\
\hline F & $1-4-8-10$ & padrão (ii): 4-8-10 \\
\hline G & $2-4-8-10$ & padrão (ii): 4-8-10 \\
\hline H & $4-7-10$ & padrão (iii): 4-7-10 \\
\hline I & $2-7-10$ & padrão (iii): 4-7-10
\end{tabular}

Por fim, faltou apenas mostrar que os padrões 3-7-10 e sua variação 1-37-10 são não-métricos em relação às grades dos decassílabos, já que o metro decassílabo não aceita duas máximas ímpares, segundo as regras da grade métrica do decassílabo: ${ }^{69}$

Num verso 3-7-10, como em (38), se tentarmos aplicar o modelo (C) para projetar a posição 3 , uma máxima na posição 7 não poderá ser projetada e isso desrespeitará a regra (26):

(38) $3-7-10$

Suplicando a compaixão do Deus forte.
$* *) * \Delta \Delta) *$
*)
*)
*) $\Delta$
$(\Delta *$
$(*$
(*
$0 \leftarrow$
$1 \rightarrow$

(Alphonsus de Guimaraens)

Se tentássemos criar uma nova regra de iteratividade para linha de grade 0 para projetar todas as máximas ímpares, a partir do modelo da regra (36), conseguiríamos montar uma grade bem formada, porém estaríamos desconsiderando a regra de iteratividade da linha de grade 0 do decassílabo, que, na verdade, é a regra que mais define o metro:

(38) Suplicando a compaixão do Deus forte.

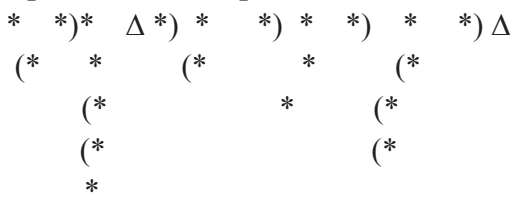

\section{(Alphonsus de Guimaraens)}

$0 \leftarrow$

${ }_{69}$ Piera (p. 102) também demonstra que o 5-8-10 também não é métrico. 
Cadernos de ESTUDOS LINGÜísTICOS (56.1) - Jan./Jun. 2014

Considerando, então, que o decassílabo não aceita duas máximas ímpares (e que aceita a acentuação na $5^{\mathrm{a}}$ e na $8^{\mathrm{a}}$, como Piera indicou pelos mesmos motivos), ${ }^{70}$ chegamos à seguinte tabela, a partir das 28 possibilidades de Proença/ Chociay:

\begin{tabular}{c|c} 
Padrões & Classificação \\
\hline $2-6-10$ & decassílabo (B) \\
\hline $3-6-10$ & decassílabo (C) \\
\hline $4-6-10$ & decassílabo (E) \\
\hline $4-7-10$ & decassílabo (H) \\
\hline $4-8-10$ & decassílabo (G) \\
\hline $1-3-6-10$ & decassílabo (C1) \\
\hline $1-4-6-10$ & decassílabo (E) \\
\hline $1-4-7-10$ & decassílabo (I) \\
\hline $1-4-8-10$ & decassílabo (F) \\
\hline $2-4-6-10$ & decassílabo (A) \\
\hline $2-4-7-10$ & decassílabo (I) \\
\hline $2-4-8-10$ & decassílabo (G) \\
\hline $2-6-8-10$ & decassílabo (B) \\
\hline $3-6-8-10$ & decassílabo (C) \\
\hline $4-6-8-10$ & decassílabo (E) \\
\hline $1-3-6-8-10$ & decassílabo (C1) \\
\hline $1-4-6-8-10$ & $\begin{array}{l}\text { decassílabo (D) } \\
\text { decassílabo (A) }\end{array}$
\end{tabular}

\begin{tabular}{c|l} 
Padrões & Classificação \\
\hline $3-7-10$ & não-métrico \\
\hline $1-3-7-10$ & não-métrico \\
\hline $1-5-7-10$ & não-métrico \\
\hline $1-5-8-10$ & não-métrico \\
\hline $2-5-7-10$ & não-métrico \\
\hline $2-5-8-10$ & não-métrico \\
\hline $3-5-7-10$ & não-métrico \\
\hline $3-5-8-10$ & não-métrico \\
\hline $1-3-5-7-10$ & não-métrico \\
\hline $1-3-5-8-10$ & não-métrico
\end{tabular}

\section{DISCUSSÃO DE PROBLEMAS DA TEORIA}

Embora a proposta de F\&H seja útil para explicar as variações acentuais do decassílabo aqui e tenha servido para tratar de variadas tradições métricas de forma tão regular na obra dos autores, precisamos apontar alguns problemas. Kiparsky (2009), Dell (2009), Hammond (2010), Hayes (2010) e Riad (2010) escreveram revisões do trabalho de $\mathrm{F} \& \mathrm{H}$ e indicaram algumas falhas, lacunas e possibilidades de desenvolvimento das ideias de F\&H. As críticas mais comuns à teoria, anotadas por todos seus revisores, são: (1) a não comparação com teorias anteriores, e (2) o retorno a uma teoria baseada em regras, quando as pesquisas mais recentes são baseadas em restrições. Nesse sentido, Hammond (2010, p.233-4) aponta, de forma prospectiva:

\section{$70 \quad$ Ver nota anterior.}


Não há nenhuma comparação com outras teorias linguísticas de metro, por exemplo, Hayes (1983), Hanson \& Kiparsky (1997) ou Golston (1998). Uma comparação da abordagem proposta aí com a de Hanson \& Kiparsky (1997) teria sido particularmente proveitosa. Igualmente, uma comparação com Golston (1998). [...] Surge outra questão acerca do caráter explicitamente baseado em regras do presente trabalho, [...]. No entanto, a maioria dos trabalhos na fonologia atual são baseados em restrição, como McCarthy \& Prinpe (1993) e Prince \& Smolensky (1993). ${ }^{71}$

Programaticamente, F\&H se dispuseram a escrever uma "nova" teoria que, embora dependa fundamentalmente dos avanços da fonologia, é "autocontida". A teoria se constrói durante a exposição de seus pressupostos e vai se explicando por meio de farta exemplificação e análise, com poucas janelas para fora.

$\mathrm{F} \& \mathrm{H}$ tentaram realmente evitar evidenciar um diálogo a todo instante com as teorias anteriores. De certa maneira, F\&H, embora tentem originalmente remigrar as bases da análise métrica das teorias baseadas em restrições para as baseadas em regras, como diz Hayes (2010, p. 3), ao fim, criam um sistema que aplica restrições (a última linha ser constituída por um só asterisco) na última instância de formação da grade de um metro.

Nesse sentido, outra crítica importante emerge: (3) a falta de delineamento de limites e contraprovas durante a exposição da teoria. Sobre a qual Riad (2010, p. 550) comenta:

A teoria proposta por Fabb \& Halle é bem diferente dos modelos anteriores, tanto em suas premissas básicas quanto, provavelmente, também em seus objetivos. Teria sido muito bem recebida se os autores tivessem esclarecido o que seria preciso para falsificar o seu modelo, e quais seriam as diferenças mais importantes com relação a modelos concorrentes anteriores. ${ }^{72}$

A revisão mais entusiasmada do trabalho de F\&H foi a de Dell (2009), que, ainda assim, tenta justificar alguns problemas em função da dimensão do propósito:

Problemas e as pontas soltas são inevitáveis em uma empresa com a dimensão e ambição do MeP. E não deveriam desviar-nos da importância da realização de Nigel Fabb e Morris Halle. Este trabalho é único pela gama e diversidade de tradições métricas que consegue reunir em uma abordagem unificada. ${ }^{73}$ (p. 413)

71 "there is no comparison to other linguistic theories of meter, e.g., Hayes (1983), Hanson \& Kiparsky (1997) or Golston (1998). A comparison of the approach proposed here with that of Hanson \& Kiparsky (1997) would have been particularly fruitful. Similarly, a comparison with Golston (1998)". [...] Another issue arises concerning the explicitly rule-based character of the present work, [...]. However, most work in current phonology is constraint-based (McCarthy \& Prince 1993, Prince \& Smolensky 1993)."

72 "The theory put forth by Fabb \& Halle is quite different from previous models, both in its basic assumptions and probably also in its goals. It would have been welcome if the authors had clarified what it would take to falsify their model, and what the most crucial differences vis-à-vis previous competing models would be."

73 "Problems and loose ends are unavoidable in an enterprise with the scale and ambition of MIP. They should not distract us from the importance of Nigel Fabb and Morris Halle's achievement. This work is unique for the range and diversity of metrical traditions that it succeeds in bringing together under a unified account." 
Já a revisão mais dura do livro de $\mathrm{F} \& H$ foi a de Kiparsky (2009). O ponto de Kiparsky é a falta de resultado disso tudo e o "solipsismo" da argumentação da teoria. Kiparsky ataca o uso de princípios derivacionais de construção de grades para caracterização do metro que, ao final, precisam ser testadas pela aplicação de restrições, criando esse "sistema híbrido". Kiparsky (2009, p. 2-3) é enfático: "não há nenhum princípio de organização métrica, [...] nenhuma análise de determinados poemas, que não pode ser, ou já foram, expressas tão bem ou melhor nas abordagens formalmente mais claras e mais perspicazes baseadas em restrição." ${ }^{\prime 4}$

Por último, a revisão de Hayes (2010) é muito sensata quando lembra que o campo da métrica é infelizmente fragmentado e que, em vez de um "trabalho de 'novos rumos' como este livro, [precisa de] algum esforço para sintetizar e desenvolver a investigação das últimas décadas" (p. 8). ${ }^{75}$ Hayes, no fim, menciona ideias que precisam ainda ser escrutinizadas e questões que requerem respostas.

Nesse mesmo sentido, pretendo anotar os problemas da teoria do decassílabo que os pressupostos de $\mathrm{F} \& \mathrm{H}$ não foram capazes de ajudar a responder, a meu ver:

(1) A noção de cabeça do verso como "posição mais forte" e mais importante para o ritmo não valoriza a posição 10 , enquanto toda métrica tradicional atribui à $10^{\mathrm{a}}$ sílaba (junto com a $6^{\mathrm{a}}$ e a $4^{\mathrm{a}}$ ) o traço distintivo do decassílabo.

Anão ser pela aplicação das próprias regras da teoria - as regras de apagamento -, a cabeça do verso na $2^{\mathrm{a}}$ posição não parece representar sua importância rítmica. Said Ali, por exemplo, parte de uma outra ideia que parece satisfatória e dialoga com os entendimentos da métrica tradicional: o que definiria o ritmo do verso (logo o que identificaria sua natureza abstrata) seria o final do verso, que, no caso do decassílabo, Said Ali entende como a seguinte sequência rítmica: ...---- $-(-)$ $(-)$, acentuando a importância da $10^{\mathrm{a}}$ sílaba.

Hayes (2010, p.6) chega a se perguntar "se a noção de 'coluna mais forte' sobre a qual a teoria se afirma pode ser defendida com evidência independente." ${ }^{.76}$

(2) A teoria de $\mathrm{F} \& \mathrm{H}$ desconsidera a declamação/leitura como elemento importante para a formação da grade. E, ao desconsiderá-la, deixa de responder a questões como a da relação das sílabas e as pausas, e o papel da duração/quantidade em metros acentuais. Said Ali (1999, p. 28) argumenta em favor de uma pausa proposital e, portanto, uma espécie de sílaba zero que conta metricamente para o verso de Gonçalves Dias, em "Seus Olhos": Às vezes, oh! sim, derramam tão fraco. Todos os 49 dodecassílabos do poema, segundo Said Ali, apresentam o mesmo esquema rítmico de quatro anfíbracos: $-\dot{-}-|-\dot{-}-|-\dot{-}-\mid-\dot{-}-$. Este verso estaria incorreto se não fosse contada a pausa na posição 6 .

74 "no principles of metrical organization, [...] no analyses of particular poems, which cannot be, or already have been, expressed as well or better in formally cleaner and more perspicuous constraint-based approaches."

75 "new directions" work such as this book, some effort to synthesize and build on the research of the past few decades."

76 "whether the notion of "strongest grid column" that it relies on can be defended with independent evidence." 
Kiparsky (2010) apresenta argumentos para a consideração de pausas como elementos métricos, mesmo na criação de uma grade métrica como a proposta por F\&H, para as canções Hausa (cf. Schuch, 1995), o verso dramático de Shakespeare e o metro do Poem in October de Dylan Thomas.

Além disso, a teoria de F\&H não abre espaço para a compreensão, diminuindo o valor absoluto não só da leitura/declamação, mas, em última análise, da própria audição/percepção. $\mathrm{O}$ arcabouço teórico de $\mathrm{F} \& \mathrm{H}$ categoriza certas acentuações como não métricas ("mal formadas") quando a "comunidade métrica" - embora tenha preferido sim determinadas acentuações, mas também muitas vezes por motivos não linguísticos - entende como métricas. Nas esteira dos trabalhos de Hale, Kissock \& Reiss (2007) e Oliveira (2009), cito Lee (2013):

Os trabalhos anteriores nas teorias da fonologia, como no modelo gerativo clássico, nos modelos não lineares e na OT, se baseiam na produção, concebendo a gramática como unidirecional, partindo de uma representação subjacente para uma representação de superfície. No entanto, não há espaço para a compreensão, que pode produzir julgamentos sobre a gramaticalidade das formas possíveis, [...].

Considerar, assim, como se processa a compreensão da grade métrica emergente do elementos constitutivos do metro, me parece um ponto interessante de pesquisa.

Os limites do métrico e não métrico, na teoria ou na prática, são naturalmente difíceis de serem traçados. Não só Sá de Miranda e Camões, mas, muito tempo depois, simbolistas e modernistas e outros poetas ainda ultimamente cultivaram o decassílabo com acentuações na $5^{\mathrm{a}}$ e $7^{\mathrm{a}}$ sílaba. Embora a teoria de F\&H os considere mal formados, quem dirá que os decassílabos de Drummond não são legítimos decassílabos, apesar de "impuros"??7

Eu quero compor um soneto duro

Como poeta algum ousara escrever.

Eu quero pintar um soneto escuro,

Seco, abafado, difícil de ler.

Quero que meu soneto, no futuro,

Não desperte em ninguém nenhum prazer.

E que, no seu maligno ar imaturo,

Ao mesmo tempo saiba ser, não ser.

Esse meu verbo antipático e impuro

Há de pungir, há de fazer sofrer,

Tendão de vênus sob o pedicuro.

Ninguém o lembrará: tiro no muro,

Cão mijando no caos, enquanto arcturo,

Claro enigma, se deixa surpreender.

${ }^{77}$ Soneto retirado de ANDRADE, C. D. Claro Enigma. In: . Obra Completa. Rio de Janeiro: Nova Aguilar, 2002. 


\section{CONSIDERAÇÕES FINAIS}

Ao final, pretendi expor com algum nível de detalhe a teoria proposta por F\&H, em Meter in Poetry: A new theory, mas sem, claramente, ter querido recriar explicações que são próprias da teoria. Seu aparato conceitual foi útil para a aplicação nos versos decassílabos da tradição poética portuguesa e brasileira. Tive como base versos desde Sá de Miranda até Januário da Cunha Barbosa, indo do século XVI ao XIX, com objetivo de não só ampliar as discussões abertas por F\&H, mas também de tentar propor uma explicação para a variedade acentual do decassílabo português.

Utilizei basicamente a metodologia de Piera (2008) e mostrei que, seguindo a teoria de $\mathrm{F} \& \mathrm{H}$, em português, podemos entender o conceito de "máxima" de forma mais abrangente. A despeito dos problemas, a teoria como pretendi descrever consegue indicar que pode haver princípios (no caso, baseados em regras de formação de grades métricas) que explicam, de forma satisfatória, a unidade do metro decassílabo e demonstram sua natureza iâmbica. Assim, do descompasso entre abordagens que aceitam apenas duas acentuações para o decassílabo e outras que entendem 28 possibilidades acentuais, o metro decassílabo emerge pelo regramento da teoria de $\mathrm{F} \& \mathrm{H}$, que configura versos como métricos e não-métricos. Considero este um grande ganho da aplicação desta teoria: poder explicar o metro através da formação de uma grade métrica que se projeta do verso, e, ao mesmo tempo, emerge do próprio metro.

Uma outra grande vantagem da proposta de F\&H é dissociar o ritmo do verso, ou seja, o ritmo não é inerente ao metro, mas surge dele. "Não há nenhum sentido em que haja um ritmo inerente, por exemplo, em um verso composto de idênticos elementos quantitativos, como num metro japonês ou num metro espondaico grego"78 (Riad, 2010, p. 547).

Além disso, embora não tenha sido objetivo mostrar isto neste trabalho, outro mérito da teoria é servir para tratar de uma grande variedade de metros.

Por fim, gostaria que esse trabalho gerasse novas discussões sobre a métrica do verso português, tão pouco estudado cientificamente. Tentei demonstrar, mesmo de forma indireta, que há muito o que ampliar nas discussões sobre os metros da tradição poética portuguesa, em especial, pela utilização de pressupostos teóricos e metodologias outras que não as tradicionais "contagens de sílabas".

\section{BIBLIOGRAFIA}

\subsection{Resenhas (reviews) de F\&H (2008)}

DELL, François. Review Article: Meter in poetry. Canadian Journal of Linguistics/Revue canadienne de linguistique, v. 54, n. 2, p. 401-415, 2009. Disponível em: http://crlao.ehess.fr/ docannexe.php?id=1107. Acesso em: 07 ago. 2013.

78 "There is no sense in which there is inherent rhythm, for example in verse made up of identical, quantitative elements, as in Japanese metre or in Greek spondaic metre." 
KIPARSKY, Paul. Review: Nigel Fabb and Morris Halle, Meter in poetry. Language, v. 85, n. 4, p. 923-930, dez. 2009. Disponível em: http://www.stanford.edu/ kiparsky/Papers/fabb halle review.pdf. Acesso em: 07 ago. 2013.

HAMMOND, Michael. Review: Nigel Fabb and Morris Halle, Meter in poetry: A new theory. Journal of Linguistics, v. 46, n. 1, p. 226-234, mar. 2010. Disponível em: http://doc. baidu.com/view/63eea3d376a20029bd642d75.html. Acesso em: 07 ago. 2013.

HAYES, Bruce. Review: Nigel Fabb and Morris Halle, Meter in poetry. Lingua, n. 120, p. 25152521, 2010. Disponível em: http://www.linguistics.ucla.edu/people/hayes/FabbHalle/ HayesReviewOfFabbHalle2008.pdf. Acesso em: 07 ago. 2013.

RIAD, Tomas. Review: Nigel Fabb and Morris Halle, Meter in poetry: A new theory. Phonology, v. 27, n. 3, p. 542-55, 2010. Disponível em: http://www.su.se/polopoly fs/1.29927. 1320939953!/Riad_review_Fabb_Halle.pdf. Acesso em: 07 ago. 2013.

\subsection{Tratados de versificação}

AZEVEDO FILHO, Leodegário A. de. A Técnica do Verso em Português. Rio de Janeiro: Acadêmica, 1971.

AZEVEDO FILHO, Leodegário A. de. O Verso Decassílabo em Português. Rio de Janeiro: Gráfica Carioca, 1963. Tese de Concurso Público de Provas e Títulos para o Cargo de Professor Catedrático da Universidade do Estado do Rio de Janeiro.

BANDEIRA, Manuel. A Versificação em Lingua Portuguesa. In: Enciclopédia Delta Larousse. Rio de Janeiro: Ed. Delta, 1964, vol. 6, p. 3239-3249.

BILAC, Olavo; PASSOS, Guimarães. Tratados de versificação. Rio de Janeiro: Francisco Alves, 1905.

CARVALHO, Amorim de. Tratado de versificação portuguesa: teoria moderna da versificação. 2. ed. Lisboa: Portugália, 1965.

CASTILHO, A. F. de. Tractado de Metrificação Portugueza. Lisboa: Imprensa Nacional, 1851.

CHOCIAY, Rogério. Teoria do Verso. São Paulo: McGraw-Hill, 1974.

DUQUE-ESTRADA, Osorio. A Arte de Fazer Versos. Rio de Janeiro: Francisco Alves, 1914,

GUERREIRO, Miguel do Couto. Tratado da Metrificação Portugueza. Lisboa: Luiz Francisco Ameno, 1784.

MATTOSO, Glauco. O Sexo do Verso Machismo e Feminismo na Regra da Poesia: Um Tratado de Versificação. São Paulo: [s.1.], 2010. Disponível em: http://normattoso.sites.uol.com.br. Acesso em: 05 mar. 2013.

NAVARRO, Tomás. Métrica española: Reseña histórica y descriptiva. 3. ed. rev. Madrid: Guadarrama, 1972.

PIMENTA, Alfredo. Tratado de Metrificação Portugueza. Lisboa: Livraria Universal, 1927.

PROENÇA, M. Cavalcanti. Ritmo e Poesia. Rio de Janeiro: Simões, 1955.

SAAVEDRA MOLINA, Julio. Tres Grandes Metros: El Eneasilabo, El Tredecasilabo y El Endecasilabo. Santiago: Prensas de la Univ. de Chile, 1946.

SAID ALI, Manuel. Versificação Portuguesa. São Paulo: Edusp, 1999 [1948]. 
6.3. Obras citadas

ATTRIDGE, Derek. The Rhythms of English Poetry. New York: Longman, 1982.

BEARE, W. The Origin of Rhythmic Latin Verse. Hermathena, n. 87, May, 1956, pp. 3-20.

BEAVER, J.C. Current Metrical Issues. College English, v. 33, n. 2, nov. 1971, p. 177-197.

BOWLEY, C. C. Metrics and the Generative Approach. Linguistics, n. 121, 1974, pp. 5-19.

BROGAN, T.V.F \& BLUMENFELD, L. Generative Metrics. In: GREENE, Roland et al. (eds.). The Princeton Encyclopedia of Poetry and Poetics. 4. ed. Princeton: Princeton University Press, 2012. p. 547-8.

BROGAN, T.V.F. English Versification, 1570-1980: A Research Guide. Baltimore: Johns Hopkins University Press, 1999 [1981]. Disponível em: http://www.arsversificandi.net/resources/. Acesso em: 10 ago. 2013.

CARNEIRO, Decio. Sá de Miranda e a sua obra. Lisboa: Antiga Casa Bertrand, 1895. Disponível em: http://www.gutenberg.org/files/27762/27762-h/27762-h.htm. Acesso em: 30 ago. 2013.

CHOCIAY, Rogério. Os metros do Boca: teoria do verso em Gregório de Matos. São Paulo: Unesp, 1993.

CHOMSKY, N. \& HALLE, M. The Sound Pattern of English. New York: Harper \& Row, 1968.

CHOMSKY, N. Language and mind. Enl. ed. New York: Harcourt, Brace, Javonovich, 1972.

CHOMSKY, N. Syntactic structures. The Hague: Mouton, 1957.

FABB, Nigel \& HALLE, Morris. Meter in poetry: a new theory. Cambridge: Cambridge University Press, 2008.

GOLSTON, Chris \& RIAD, Tomas. The phonology of Classical Greek meter. Linguistics, n. 38, 2000, p. 99-167.

GOLSTON, Chris. Constraint-based metrics. Natural Language and Linguistic Theory, n. 16, 1998, p.719-770.

HALE, Mark; KISSOCK, Madelyn; REISS, Charles. Microvariation, variation, and the features of universal grammar. Lingua, 117, 2007. p.645-665.

HALLE, M. \& KEYSER, S. J. Chaucer and the study of prosody. College English, n. 28, 1966. p. 187-219.

HALLE, Morris \& KEYSER, S.J. English stress: its form, its growth, and its role in meter. New York: Harper and Row, 1971.

HALLE, Morris \& KEYSER, S.J. English: The iambic pentameter. In: WIMSATT, W. (ed.). Versification: Major Language Types. New York: New York UP, 1972, p. 217-237. (Reprinted in FREEMAN, D.C. (ed.). Essays in modern stylistics. London: Methuen, 1981)

HAMMOND, Michael. Poetic meter and the arboreal grid. Language, n. 67, 1991, p. 240-259.

HANSON, Kristin \& KIPARSKY, Paul. A parametric theory of poetic meter. Language, n. 72, 1996, p. 287-335. 
HANSON, Kristin. Generative metrics: the state of the art. In: KÜPER, Christoph. Current trends in metrical analysis. Frankfurt: Peter Lang, 2011, pp. 45-62.

HANSON, Kristin. Metrical alignment. In: AROUI, Jean-Louis \& ARLEO, Andy (eds.). Towards a typology of poetic forms. Amsterdam: John Benjamins, 2009a.

HANSON, Kristin. Nonlexical word stress in the English iambic pentameter: a study of John Donne. In: HANSON, Kristin \& INKELAS, Sharon. (eds.). The Nature of the Word: Studies in Honor of Paul Kiparsky. Cambridge: MIT Press, 2009b, pp. 21-62.

HAYES, Bruce. A grid-based theory of English meter. Linguistic Inquiry, n. 14, 1983, p. 357-393.

HAYES, Bruce. Introductory Phonology. London: Blackwell, 2008.

HAYES, Bruce. Metrical stress theory: principles and case studies. Chicago: University of Chicago Press, 1995.

HAYES, Bruce. Metrics and phonological theory. In: NEWMEYER, Frederick J. (ed.). Linguistics: The Cambridge Survey, vol. 2: Linguistic theory: Extensions and Implications, p. 220-249, Cambridge: Cambridge University Press, 1988.

HAYES, Bruce. The prosodic hierarchy in meter. In: KIPARSKY, Paul \& YOUMANS, Gilbert (eds.). Phonetics and phonology, vol. 1: Rhythm and meter. San Diego: Academic Press, 1989. p. 201-26.

HOLDER, Alan. Recent Prosodic Commentary. In: Rethinking Meter: A New Approach to the Verse Line. Londres, Associated Universities Presses, 1995. p. 65-84.

JAKOBSON, Roman. Linguística e Poética. In: . Linguística e Comunicação. 26 ed. Tradução de Izidoro Blikstein e José Paulo Paes. São Paulo: Cultrix, 2011, p.118-162.

KEYSER, S. J. Old English prosody. College English, n. 30, 1969, p. 331-56.

KIPARSKY, Paul. Meter and Performance. In: LSA Metrics Symposium, 8 jan., 2010.

KIPARSKY, Paul. Stress, syntax, and meter. Language, n. 51, 1975, p. 576-616.

KIPARSKY, Paul. The rhythmic structure of English verse. Linguistic Inquiry, n. 8, 1977, pp. 189-247.

LEE, Seung-Hwa. Variação fonológica e Fonologia como a Gramática de Compreensão, Organon, v. 28, n. 54, 2013.

LIBERMAN, Mark \& PRINCE, Alan. On stress and linguistic rhythm. Linguistic Inquiry, n. 8, 1977, p. 249-336.

LIBERMAN, Mark. The intonational system of English. PhD thesis, MIT, 1975.

MACAMBIRA, José Rebouças. Estrutura Musical do Verso e da Prosa. Fortaleza: Pioneira, 1983.

MACHADO, José de Sousa. O Poeta do Neiva: Notícias Biográficas e Genealógicas. Braga: Livraria Cruz, 1929.

MAGNUSON, Karl \& RYDER, Frank G. Second Thoughts on English Prosody. College English, n. 33, 1971, p. 198-216.

MAGNUSON, Karl \& RYDER, Frank G. The Study of English Prosody: An Alternative Proposal. College English, n. 31, 1970, p. 789-820. 
OLIVEIRA, Marco Antonio de. Variação fonológica: o indivíduo e a comunidade de fala. In: CORTINA, Arnaldo; NASSER, Sílvia Maria Gomes da Conceição. (org.). Sujeito e linguagem. 17ed. São Paulo: Cultura Acadêmica, 2009, v. 1, p. 97-116.

PIERA, Carlos. Southern Romance. In: FABB, Nigel \& HALLE, Morris. Meter in poetry: a new theory. Cambridge: Cambridge University Press, 2008, p. 94-132.

PIERA, Carlos. Spanish verse and the theory of meter. Ph.D. Dissertation, University of California, Los Angeles. 1980.

PRINCE, Alan. Metrical forms. Phonetics and phonology. In: KIPARSKY, Paul \& YOUMANS, Gilbert (eds.). Rhythm and meter. San Diego: Academic Press, 1989, pp. 305-340.

PRINCE, Alan. Relating to the grid. Linguistic Inquiry, n. 14, 1983, p. 19-100.

SILVA RAMOS, Péricles Eugênio. O Verso Romântico e Outros Ensaios. São Paulo: Conselho Estadual de Cultura, 1959.

SLEDD, John. Old English Prosody: A Demurrer, College English, 31, Oct., 1969, p. 71-74.

STEELE, Timothy. Missing Measures: Modern Poetry and the Revolt Against Meter. Fayetteville: University of Arkansas Press, 1990. 
ALVAREZ - A Teoria do metro de Fabb \& Halle e o Decassílabo Português

APÊNDICE 1 - Padrões acentuais nos manuai ${ }^{\mathrm{s}}$

\begin{tabular}{|c|c|c|c|}
\hline Ano & Autor & Padrões acentuais descritos & Modelos \\
\hline 1615 & Nunes $^{79}$ & $?$ & $?$ \\
\hline 1784 & Guerreiro & $6-10$ & Heroico \\
\hline 1851 & Castilho & $\begin{array}{l}6-10,2-4-6-8-10,2-6-8-10,2-6-10,3-6-10 \\
4-8-10 \\
2-7-10,4-7-10\end{array}$ & $\begin{array}{l}\text { Heroico } \\
\text { Sáfico } \\
\text { Provençal }\end{array}$ \\
\hline 1905 & Bilac \& Passos & $\begin{array}{l}2-4-8-10 \\
2-4-6-10,1-3-6-10,2-4-6-8-10,3-6-10\end{array}$ & $\begin{array}{l}\text { Sáfico } \\
\text { Heroico }\end{array}$ \\
\hline 1914 & Duque-Estrada & $6-10,(2,3,4)-6-10,(1,2)-4-6-10$ & Heroico \\
\hline 1928 & Pimenta & $\begin{array}{l}6-10 \\
4-8-10 \\
6-10,4-7-10,4-10,5-7-10,4-8-10,5-10\end{array}$ & $\begin{array}{l}\text { Heroico } \\
\text { Sáfico } \\
\text { Trovadoresco }\end{array}$ \\
\hline 1941 & Carvalho & $\begin{array}{l}6-10 \\
4-8-10 \\
5+5 ?, 4 / 1+5 ?, 4+6 ?\end{array}$ & $\begin{array}{l}\text { Heroico } \\
\text { Sáfico } \\
\text { Medieval/trovadoresco }\end{array}$ \\
\hline 1948 & Said Ali & $\begin{array}{l}2-4-6-8-10,2-6-8-10,3-6-8-10,1-3-6-8-10 \\
1-6-8-10,1-4-6-8-10 \\
1-4-8-10,2-4-8-10 \\
4 / 1+5 / 1,5+5 / 1\end{array}$ & $\begin{array}{l}\text { Heroico } \\
\text { Sáfico } \\
\text { Ibérico/arte maior }\end{array}$ \\
\hline 1955 & Proença & 21 (28) possibilidades & \\
\hline 1962 & Azevedo Filho & $\begin{array}{l}6-10 \\
4-8-10 \\
+5 \text { possibilidades acentuais }\end{array}$ & $\begin{array}{l}\text { Heroico } \\
\text { Sáfico } \\
\text { Medievais/trovadoresco }\end{array}$ \\
\hline 1964 & Bandeira & $\begin{array}{l}6-10 \\
4-8-10 \\
4-7-10,2-7-10 \\
5-8-10,5-7-10\end{array}$ & $\begin{array}{l}\text { Heroico } \\
\text { Sáfico } \\
\text { Gaita galega } \\
\text { "Franceses" }\end{array}$ \\
\hline 1971 & Azevedo Filho & $\begin{array}{l}6-10 \\
4-8-10 \\
4-7-10 \\
3-7-10 \\
5-10 \\
4-10\end{array}$ & $\begin{array}{l}\text { Heroico } \\
\text { Sáfico } \\
\text { Gaita galega/muñieras } \\
\text { Lírica provençal } \\
\text { Arte maior } \\
\text { Lírica trovadoresca }\end{array}$ \\
\hline 1974 & Chociay & 28 possibilidades & \\
\hline
\end{tabular}

${ }^{79}$ Embora haja registro em outros autores do simplificado tratamento do tema em Nunes (1615), não consegui acesso à obra em tempo. 
APÊNDICE 2 - Padrões acentuais nos poemas

196 versos de sonetos de Sá de Miranda, Camões e Claudio Manoel da Costa ${ }^{80}$

\begin{tabular}{|l|l|c|c|}
\hline Padrão & \multicolumn{1}{|c|}{ Acentuação } & \# versos & $\%$ versos \\
\hline A & $2-4-6-8-10$ & 47 & $24,0 \%$ \\
\hline B & $2-6-8-10$ & 46 & $23,5 \%$ \\
\hline C/C1 & $(1)-3-6-8-10$ & 47 & $24,0 \%$ \\
\hline D & $1-6-10$ & 8 & $4,1 \%$ \\
\hline E & $1-4-6-10$ & 29 & $14,8 \%$ \\
\hline F/G & $(1 / 2)-4-8-10$ & 13 & $6,6 \%$ \\
\hline H/I & $2-4-7-10$ & 1 & $0,5 \%$ \\
\hline prov & $4-10$ & 4 & $2,0 \%$ \\
\hline trov & $2-5-7-10$ & 1 & $0,5 \%$ \\
\hline & & 196 & $100 \%$ \\
\hline
\end{tabular}

Poema Niterói, de Januário da Cunha Barbosa ${ }^{81}$

\begin{tabular}{|l|l|c|c|}
\hline Padrão & \multicolumn{1}{|c|}{ Acentuação } & \# versos & $\%$ versos \\
\hline A & $2-4-6-8-10$ & 114 & $48 \%$ \\
\hline B & $2-6-8-10$ & 31 & $13 \%$ \\
\hline C/C1 & $(1)-3-6-8-10$ & 68 & $28 \%$ \\
\hline F/G & $(1 / 2)-4-8-10$ & 26 & $11 \%$ \\
\hline & & 239 & $100 \%$ \\
\hline
\end{tabular}

Versos de Camões a Bilac - Macambira (1983, p.95)

\begin{tabular}{|l|c|c|}
\hline Padrão & Acentuação & $\%$ versos \\
\hline $1^{\circ}$ DPD $^{82}$ & $3-6-10$ & $31,3 \%$ \\
\hline $2^{\circ}$ PPT & $2-4-6-8-10$ & $28,2 \%$ \\
\hline $3^{\circ} \mathrm{PTP}$ & $2-4-8-10$ & $22, \%$ \\
\hline $4^{\circ} \mathrm{TPP}$ & $1-4-6-10$ & $17,1 \%$ \\
\hline & & 198 versos \\
\hline
\end{tabular}

${ }^{80}$ Para a escansão completa desses versos, acessar http://www.uff.br/lingualatina/decassilabo.

${ }^{81}$ Para acessar a versão atualizada da obra de Cunha Barbosa, ver http://www.uff.br/lingualatina/ nicteroy. O número de 239 versos escandidos equivale a aproximadamente metade dos 477 versos do poema.

${ }^{82}$ Macambira descreve os versos como sucessão de pés: $\mathrm{P}$, peônio; T, troqueu; e D, dátilo. 
Verso de Gregório de Matos - Chociay (1993, p. 52)

\begin{tabular}{|l|c|}
\hline \multicolumn{1}{|c|}{ Padrão/Acentuação } & \# versos \\
\hline $\begin{array}{l}\text { Decassílabo italiano: } \\
\text { 6-10 e 4-8-10 }\end{array}$ & 3798 \\
\hline $5-10$ & 16 \\
\hline 4-7-10 & 10 \\
\hline
\end{tabular}

